\title{
Aditivos microbiológicos em silagens no Brasil: revisão dos aspectos da ensilagem e do desempenho de animais
}

\author{
Maity Zopollatto', João Luiz Pratti Daniel ${ }^{1}$, Luiz Gustavo Nussion \\ ${ }^{1}$ Departamento de Zootecnia, USP/ESALQ, Piracicaba/SP.
}

RESUMO - O uso de inoculantes microbianos no Brasil vem aumentando nos últimos anos, embora o número de trabalhos ainda seja pequeno quando comparado aos observados no exterior, principalmente no que se refere ao desempenho de animais. Nos estudos com silagens de milho e sorgo os inoculantes avaliados foram compostos exclusivamente de bactérias homofermentativas, que também representaram a maioria das pesquisas em silagens de capins, enquanto que nas silagens de cana-de-açúcar predominou o uso de bactérias heterofermentativas. Em geral, o uso de bactérias homofermentativas apresentou resultados favoráveis apenas para as silagens de milho e capins, traduzidos na maioria das vezes por menores teores de fibra e valor de pH, compensados pelo maior teor de PB. No caso das heterofermentativas foram encontrados bons resultados principalmente para as silagens de cana-de-açúcar, com menor pH e teor de compostos fibrosos em face aos aumentos do teor de carboidratos solúveis, associado à maior recuperação de MS e aumento de estabilidade aeróbia. A associação de bactérias hetero e homofermentativas proporcionou respostas satisfatórias e potencialmente interessantes embora os dados nacionais ainda sejam escassos. Investimentos adicionais na interface forragem:microrganismo poderá permitir exploração de novas perspectivas de aplicação e consolidação das recomendações desses aditivos.

Palavras-chave: inoculante, silagem de milho, silagem de sorgo, silagem de cana-de-açúcar, silagem de capim, microganismo

\section{Microbial silage additives in Brazil: review of aspects of ensilage and animal performance}

\begin{abstract}
In recent years, the use of microbial inoculants has been increased in Brazil, although the number of trials is still behind the international standards, mainly regarding animal performance data. In corn and sorghum silages studies, homofermentative bacteria represented the exclusive source of inoculants evaluated, which in turn, were also the major inoculant used for tropical grass silages research, whereas in sugar cane silages predominated heterofermentative bacteria. Usually, the application of homofermentative bacteria showed favorable results only for corn and grass silages, based on the lower fiber content and $\mathrm{pH}$ values, offset by the higher PB levels. Heterofermentative bacteria were useful mainly for the sugar cane silages, leading to lower $\mathrm{pH}$ values and fiber content and increased aerobic stability which promoted higher DM recovery rate and soluble carbohydrate content. The combination of the two groups of bacteria showed positive and potentially interesting results although the national database are still under development. Additional research efforts on the interface forage source:microorganisms might enhance the opportunities, offer new enterprise for the utilization and better establish reliable conditions for recommendation of microbial additives for silage.
\end{abstract}

Key Words: corn silage, grass silage, inoculant, microrganisms, sorghum silage, sugar cane silage

\section{Introdução}

O uso de aditivos microbiológicos em silagens tem o objetivo de inibir o crescimento de microrganismos aeróbios (especialmente aqueles associados com instabilidade aeróbia, ex. leveduras, Listeria), inibir o crescimento de organismos anaeróbios indesejáveis como enterobactérias e clostrídeos, inibir a atividade de proteases e deaminases da planta e de microrganismos, adicionar microrganismos benéficos para dominar a fermentação, formar produtos finais benéficos para estimular o consumo e a produção do animal e melhorar a recuperação de matéria seca da forragem conservada (Kung Jr. et al., 2003).

Inoculantes microbianos usados como aditivos incluem bactérias homofermentativas, heterofermentativas, ou a combinação destas. Os microrganismos homofermentativos caracterizam-se pela taxa de fermentação mais rápida, menor proteólise, maior concentração de ácido lático, menores 
teores de ácidos acético e butírico, menor teor de etanol, e maior recuperação de energia e matéria seca. Bactérias heterofermentativas utilizam ácido lático e glicose como substrato para produção de ácido acético e propiônico, os quais são efetivos no controle de fungos, sob baixo $\mathrm{pH}$.

A obtenção de sucesso no uso de aditivos microbiológicos em silagens depende da habilidade da bactéria inoculada crescer rapidamente na massa de forragem ensilada, da presença de substrato adequado e da população de bactérias inoculadas em relação à população epífita da forragem. São necessárias aproximadamente $10^{8}$ bactérias ácido láticas por grama de forragem para que o $\mathrm{pH}$ decline rapidamente. No entanto, esta concentração é muito superior à suprida pelos aditivos microbiológicos, e neste caso, o inoculante deve apresentar rápida taxa de crescimento na forragem recém armazenada (Muck, 1988).

São apontadas algumas hipóteses para o insucesso da utilização de inoculantes em silagens. Dentre elas destacamse: a atividade competitiva de população epífita da planta originada apartir de cepas selvagens, o baixo teor de açúcares da forragem, os efeitos do antecedente histórico da cultura agrícola utilizada como fonte de forragem, excesso de oxigênio, extremos de atividade de água na massa ensilada, problemas na aplicação do produto (Muck \& Kung Jr., 1997; Kung Jr. et al, 2003).

O presente trabalho objetivou realizar um levantamento dos artigos publicados em periódicos científicos nacionais, à saber: a Revista Brasileira de Zootecnia, Revista Scientia Agricola, Acta Scientiarum-Animal Science, Pesquisa Agropecuária Brasileira, Boletim da Indústria Animal,
Brazilian Journal of Veterinary Research and Animal Science e Arquivos Brasileiros de Medicina Veterinária e Zootecnia. Foram avaliados apenas os trabalhos publicados na última década (1999-2009), referentes às culturas de milho, sorgo, cana-de-açúcar e capins tropicais. Para a realização do levantamento adotou-se o critério de selecionar os artigos contendo as forragens supracitadas, desde que essas referências contivessem obrigatoriamente um tratamento controle (sem aditivo) para permitir a comparação e o cálculo do diferencial de resposta em relação ao tratamento contendo o aditivo microbiológico advindo, exclusivamente, de fontes comerciais. Assim, foram selecionados 43 trabalhos que atenderam os requisitos especificados e, com essa estratégia não foram incluídos cinco artigos científicos correlatos que não atenderam essa condição (Andrade et al., 2000; Guim et al., 2002; Jobim et al., 2006; Freitas et al., 2006b; Gentil et al., 2007).

A Figura 1 apresenta a distribuição dos trabalhos encontrados ao longo dos dez anos (1999-2009) de avaliação e foram considerados nesse estudo oito trabalhos relativos à silagem de milho, seis contendo silagem de sorgo, 14 utilizados em silagem de cana-de-açúcar e 15 trabalhos com silagens de capins tropicais.

Para avaliar os efeitos dos aditivos microbiológicos sobre os parâmetros estudados estabeleceu-se um valor de diferencial de resposta (tratado versus controle), cuja descrição segue na Tabela 1, onde são apresentados critérios de interpretação e sugestão de valores desejáveis.

O diferencial de resposta foi calculado de acordo com fórmula apresentada a seguir, e considerou apenas

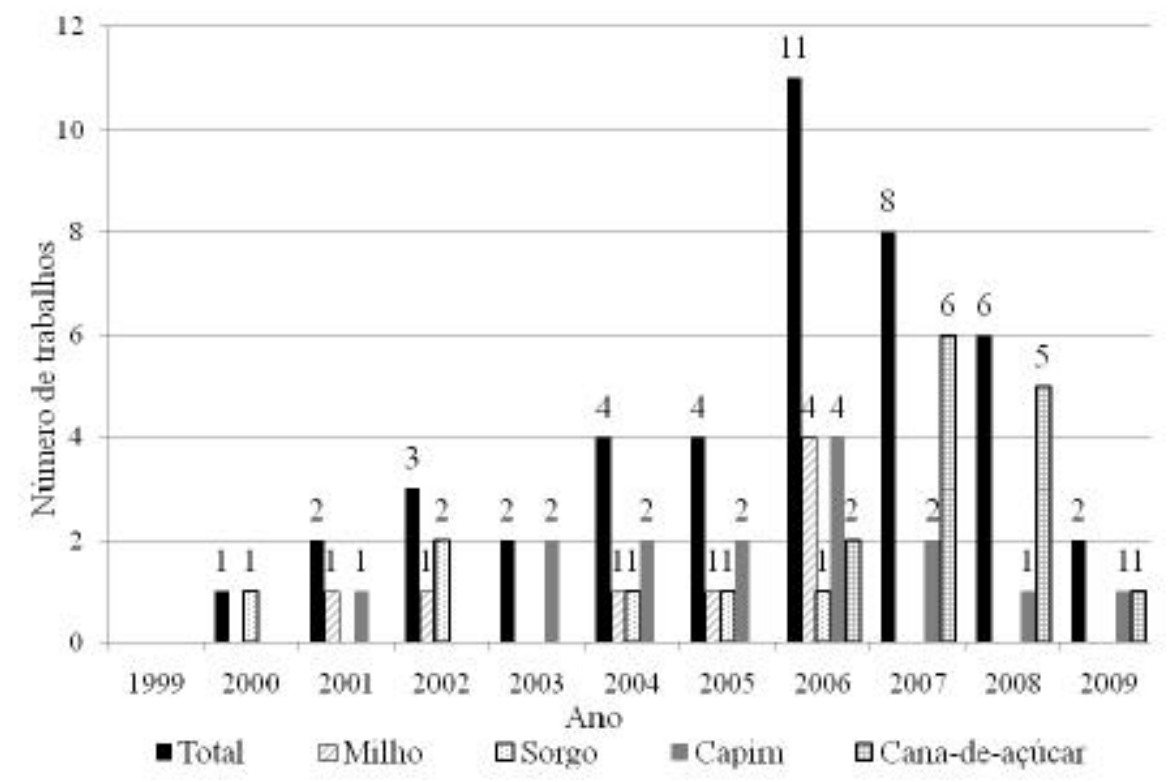

Figura 1 - Trabalhos publicados em periódicos nacionais na última década (1999-2009), avaliando a presença de aditivos microbiológicos em silagens. 
Tabela 1 - Valores de diferencial de resposta $(\Delta)$ considerados como favoráveis nos artigos avaliados

\begin{tabular}{|c|c|c|c|c|c|}
\hline Valor nutritivo & $\operatorname{Delta}(\Delta)$ & Parâmetros fermentativos & $\operatorname{Delta}(\Delta)$ & Desempenho & $\operatorname{Delta}(\Delta)$ \\
\hline MS, $\%$ & $>0$ & $\mathrm{pH}$ & $<0$ & $\mathrm{CMS}, \% \mathrm{PV}$ & $>0$ \\
\hline $\mathrm{MM}, \% \mathrm{MS}$ & $<0$ & Etanol, \% MS & $<0$ & CMSD, \% PV & $>0$ \\
\hline $\mathrm{PB}, \% \mathrm{MS}$ & $>0$ & Acético, \% MS & 0 hetero e $<0$ homo & CNDT, \%PV & $>0$ \\
\hline NIDN, \% N & $<0$ & Propiônico, \% MS & $>0$ & CFDN, \% PV & $>0$ \\
\hline NIDA, \% N & $<0$ & Butírico, \% MS & $<0$ & $\mathrm{GP}, \mathrm{kg} / \mathrm{dia}$ & $>0$ \\
\hline $\mathrm{FB}, \% \mathrm{MS}$ & $<0$ & Lático, \% MS & $>0$ & $\mathrm{CA}, \mathrm{kg} \mathrm{MS} / \mathrm{kg}$ ganho & $<0$ \\
\hline FDN, \% MS & $<0$ & Rel. Lático:Acético & 0 homo e $<0$ hetero & DAMS, $\%$ & $>0$ \\
\hline FDA, \% MS & $<0$ & $\mathrm{~N}-\mathrm{NH} 3, \% \mathrm{~N}$ total & $<0$ & DAFDN, \% MS & $>0$ \\
\hline CEL, \% MS & $<0$ & Estabilidade aeróbia, h & $>0$ & DIVMS, \% & $>0$ \\
\hline HEM, \% MS & $<0$ & Poder tampão, $\mathrm{mEq} / 100 \mathrm{~g} \mathrm{M}$ & $<0$ & & \\
\hline LIG, \% MS & $<0$ & Perdas de MS, \% & $<0$ & & \\
\hline ENN, \% MS & $>0$ & Perdas de gases, $\%$ MS & $<0$ & & \\
\hline $\mathrm{CNF}, \% \mathrm{MS}$ & $>0$ & Perda de efluente, $\mathrm{kg} / \mathrm{t} \mathrm{MV}$ & $<0$ & & \\
\hline Amido, \% MS & $>0$ & Recuperação de MS, \% & $>0$ & & \\
\hline $\mathrm{CHO}, \% \mathrm{MS}$ & $>0$ & Recuperação de MSD, \% & $>0$ & & \\
\hline \multirow[t]{3}{*}{$\mathrm{EE}, \% \mathrm{MS}$} & $>0$ & Recuperação de CNF, \% & $>0$ & & \\
\hline & Mofo e leveduras, ufc/g & $<0$ & & & \\
\hline & BAL, ufc/g & $>0$ & & & \\
\hline
\end{tabular}

MS - matéria seca; MO - matéria orgânica; PB - proteína bruta; FB - fibra bruta; MM - matéria mineral; ENN - extrativos não nitrogenados; EE - extrato etéreo; FDN fibra em detergente neutro; FDA - fibra em detergente ácido; CEL - celulose; HEM - hemicelulose; CHO - carboidratos; LIG - lignina; NIDN - nitrogênio insolúvel em detergente neutro; NIDA - nitrogênio insolúvel em detergente ácido; CNF - carboidratos não fibrosos; N-NH3 - nitrogênio amoniacal; BAL - bactérias ácido láticas; CMS - consumo de MS; CMSD - consumo de MS digestível; CNDT - consumo de nutrientes digestíveis totais; CFDN - consumo de FDN; GP - ganho de peso diário; CA - conversão alimentar; DAMS - digestibilidade aparente da MS; DAFDN - digestibilidade aparente do FDN; DIVMS - digestibilidade in vitro da MS;

resultados onde a comparação foi declarada como estatisticamente significativa. Nos casos onde não foi detectada diferença significativa para a presença do inoculante adotou-se como 0 o valor de diferencial de resposta:

$$
\begin{gathered}
\text { Diferencial de resposta " } \Delta "(\%)= \\
{\left[\frac{\text { Valor do Tratado- Valor do Contole }}{\text { Valor do Controle }}\right] \times 100}
\end{gathered}
$$

As Tabelas 2, 3 e 4 apresentam, respectivamente, as variações encontradas nos artigos para as variáveis relacionadas ao valor nutritivo, parâmetros fermentativos das silagens e desempenho de animais alimentados com as silagens controle ou aditivadas com microrganismos.

Nos trabalhos avaliados observou-se grande diversidade de microrganismos utilizados na inoculação, dentre eles bactérias homofermentativas (Lactobacillus plantarum, Lactobacillus curvatus, Lactobacillus acidophilus, Lactobacillus spp., Streptococcus faecium, Pediococcus pentosaceus e Pediococcus acidilactici), bactérias heterofermentativas Lactobacillus buchneri, Lactobacillus brevis e Propionibacterium) ou a mistura de hetero e homofermentativas, sendo que em alguns produtos comerciais há ainda a inclusão de enzimas (amilase, celulase, hemicelulases) no inoculante.

A maior parte das enzimas utilizadas como aditivos em silagens são subprodutos microbianos com alguma atividade enzimática. O princípio de utilização de enzimas é o de estimular a quebra de carboidratos complexos (amidos, celulose e hemicelulose) em açúcares simples que seriam prontamente fermentados pelas bactérias ácido láticas (Vilela, 1998).

\section{Silagem de milho}

Nos oito trabalhos avaliados com silagem de milho (Backes et al., 2001; Rodrigues et al., 2002; Rodrigues et al., 2004; Silva et al., 2005; Rocha et al., 2006; Gimenes et al., 2006a; Gimenes et al., 2006b; Silva et al., 2006)observou-se que todos utilizaram aditivos contendo bactérias homofermentativas, normalmente mais de uma cepa, sendo que em quatro casos notou-se a presença de bactérias homofermentativas mais enzimas e as doses de aplicação dos inoculantes variaram entre $1 \times 10^{5}$ e $9 \times 10^{9} \mathrm{ufc} / \mathrm{g}$ de forragem fresca.

As variações observadas nos parâmetros fermentativos das silagens de milho (Tabela 3 ) sugerem que os teores de ácido lático estão abaixo do considerado adequado (4-6\% MS) em silagens bem fermentadas (Roth \& Undersander, 1995). Além disso, os valores observados para N-amoniacal e NIDA são superiores aos recomendados pelos autores, que preconizam relações dessas frações em relação ao $\mathrm{N}$ total, inferior a 5 e $12 \%$, respectivamente.

Dos resultados avaliados observou-se que 66,7; 33,3 e $22,2 \%$, respectivamente, apresentaram menores teores de celulose, hemicelulose e FDN nas silagens aditivadas, respectivamente, enquanto $10 \%$ dos dados encontrados 
Tabela 2 - Variações no valor nutritivo de silagens de milho, sorgo, cana-de-açúcar e capim encontradas nos artigos avaliados

\begin{tabular}{|c|c|c|c|c|c|c|c|c|c|c|c|c|c|c|c|c|}
\hline \multirow[b]{2}{*}{ Parâmetro } & \multicolumn{4}{|c|}{ Silagem de milho } & \multicolumn{4}{|c|}{ Silagem de sorgo } & \multicolumn{4}{|c|}{ Silagem de cana-de-açúcar } & \multicolumn{4}{|c|}{ Silagem de capim } \\
\hline & $\mathrm{n}$ & Média & Mín & Máx & $\mathrm{n}$ & Média & Mín & Máx & $\mathrm{n}$ & Média & Mín & Máx & $\mathrm{n}$ & Média & Mín & Máx \\
\hline MS, \% & 22 & 34,6 & 28,2 & 48,3 & 21 & 31,0 & 23,5 & 41,7 & 26 & 25,1 & 19,3 & 34,1 & 33 & 20,4 & 14,4 & 29,9 \\
\hline MM, \% MS & 2 & 3,0 & 2,7 & 3,2 & 2 & 3,8 & 3,6 & 4,0 & 13 & 5,1 & 1,8 & 7,4 & 8 & 11,0 & 9,3 & 12,1 \\
\hline $\mathrm{PB}, \% \mathrm{MS}$ & 22 & 7,9 & 6,4 & 10,2 & 21 & 8,5 & 5,5 & 14,1 & 26 & 3,2 & 1,7 & 5,1 & 30 & 8,1 & 4,4 & 13,4 \\
\hline NIDN, \% N & 3 & $1,3^{*}$ & $0,3^{*}$ & $3,2^{*}$ & 0 & - & - & - & 3 & 44,4 & 35,1 & 55,8 & 2 & 17,3 & 16,0 & 18,5 \\
\hline NIDA, \% N & 4 & 24,8 & 23,1 & 27,0 & 4 & 28,3 & 27,6 & 29,0 & 0 & - & - & - & 10 & 14,2 & 11,3 & 17,7 \\
\hline $\mathrm{FB}, \% \mathrm{MS}$ & 4 & 22,9 & 21,9 & 23,8 & 2 & 31,0 & 30,5 & 31,4 & 0 & - & - & - & 2 & 39,8 & 38,3 & 41,3 \\
\hline FDN, \% MS & 20 & 55,3 & 42,8 & 66,5 & 21 & 55,7 & 39,1 & 64,3 & 26 & 65,1 & 49,1 & 75,3 & 28 & 71,7 & 61,1 & 82,3 \\
\hline FDA, \% MS & 17 & 30,5 & 22,9 & 42,5 & 18 & 31,9 & 22,5 & 42,1 & 23 & 42,5 & 34,6 & 48,7 & 24 & 46,1 & 33,4 & 53,9 \\
\hline CEL, \% MS & 8 & 22,9 & 17,3 & 27,5 & 17 & 26,0 & 19,5 & 29,3 & 3 & 35,5 & 34,5 & 36,6 & 12 & 37,3 & 29,5 & 42,7 \\
\hline HEM, \% MS & 8 & 25,3 & 22,3 & 30,2 & 17 & 25,0 & 21,3 & 30,2 & 11 & 24,7 & 19,7 & 30,5 & 12 & 24,7 & 20,5 & 29,6 \\
\hline LIG, \% MS & 9 & 7,8 & 2,5 & 13,1 & 14 & 5,9 & 3,1 & 9,3 & 11 & 7,2 & 5,0 & 9,8 & 17 & 7,2 & 4,1 & 12,5 \\
\hline ENN, \% MS & 2 & 63,4 & 62,6 & 64,3 & 2 & 55,3 & 53,9 & 56,7 & 0 & - & - & - & 0 & - & - & - \\
\hline $\mathrm{CNF}, \% \mathrm{MS}$ & 2 & 30,5 & 29,5 & 31,6 & 2 & 22,6 & 21,4 & 23,8 & 3 & 18,9 & 14,9 & 24,9 & 18 & - & - & - \\
\hline Amido, $\%$ MS & 6 & 24,9 & 23,3 & 27,2 & 6 & 13,6 & 6,2 & 19,3 & 0 & - & - & - & 6 & 12,3 & 1,4 & 18,6 \\
\hline $\mathrm{CHO}, \% \mathrm{MS}$ & 7 & 7,7 & 6,3 & 8,7 & 12 & 2,3 & 0,1 & 7,3 & 19 & 5,1 & 0,7 & 15,9 & 0 & 1,6 & 0,5 & 2,7 \\
\hline EE, \% MS & 7 & 2,7 & 1,9 & 3,0 & 4 & 2,1 & 1,9 & 2,4 & 0 & - & - & - & 4 & 2,0 & 1,4 & 2,8 \\
\hline
\end{tabular}

$\mathrm{n}=$ número de dados que geraram as médias.

MS - matéria seca; MO - matéria orgânica; PB - proteína bruta; FB - fibra bruta; MM - matéria mineral; ENN - extrativos não nitrogenados; EE - extrato etéreo; FDN fibra insolúvel em detergente neutro; FDA - fibra insolúvel em detergente ácido; CEL - celulose; HEM - hemicelulose; CHO - carboidratos; LIG - lignina; NIDN nitrogênio insolúvel em detergente neutro; NIDA - nitrogênio insolúvel em detergente ácido; CNF - carboidratos não-fibrosos.

* Valores em \% de FDN.

Tabela 3 - Variações nos parâmetros fermentativos de silagens de milho, sorgo, cana-de-açúcar e capim encontradas nos artigos avaliados

\begin{tabular}{|c|c|c|c|c|c|c|c|c|c|c|c|c|c|c|c|c|}
\hline \multirow[b]{2}{*}{ Parâmetro } & \multicolumn{4}{|c|}{ Silagem de milho } & \multicolumn{4}{|c|}{ Silagem de sorgo } & \multicolumn{4}{|c|}{ Silagem de cana-de-açúcar } & \multicolumn{4}{|c|}{ Silagem de capim } \\
\hline & $\mathrm{n}$ & Média & Mín & Máx & $\mathrm{n}$ & Média & Mín & Máx & $\mathrm{n}$ & Média & Mín & Máx & $\mathrm{n}$ & Média & Mín & Máx \\
\hline $\mathrm{pH}$ & 12 & 3,9 & 3,3 & 4,4 & 16 & 3,8 & 3,7 & 4,1 & 25 & 3,4 & 2,7 & 3,8 & 36 & 4,5 & 3,5 & 5,3 \\
\hline Etanol, \% MS & 4 & 0,1 & 0,1 & 0,1 & 4 & 3,3 & 2,4 & 3,7 & 19 & 7,8 & 0,3 & 21,8 & 4 & 0,9 & 0,9 & 1,0 \\
\hline Acético, \% MS & 4 & 2,7 & 2,5 & 2,8 & 12 & 1,5 & 0,8 & 2,9 & 14 & 4,0 & 1,6 & 9,3 & 12 & 1,5 & 0,3 & 3,4 \\
\hline $\begin{array}{l}\text { Propiônico } \\
\text { (\% MS) }\end{array}$ & 4 & 0,0 & 0,0 & 0,0 & 4 & 0,0 & 0,0 & 0,0 & 9 & 0,7 & 0,2 & 1,9 & 6 & 0,1 & 0,0 & 0,2 \\
\hline Butírico, \% MS & 4 & 0,0 & 0,0 & 0,0 & 4 & 0,0 & 0,0 & 0,0 & 6 & 0,1 & 0,0 & 0,1 & 12 & 0,0 & 0,0 & 0,1 \\
\hline Lático, \% MS & 4 & 1,4 & 1,0 & 1,7 & 14 & 6,1 & 4,1 & 8,5 & 12 & 3,3 & 0,8 & 6,3 & 14 & 4,2 & 0,0 & 9,3 \\
\hline Rel. Lat:Ace & 0 & - & - & - & 0 & - & - & - & 0 & - & - & - & 4 & 8,0 & 6,5 & 10,2 \\
\hline $\begin{array}{l}\mathrm{N}-\mathrm{NH}_{3} \\
(\% \mathrm{~N} \text { total })\end{array}$ & 10 & 8,5 & 7,0 & 10,1 & 10 & 5,7 & 0,3 & 15,3 & 12 & 6,4 & 1,8 & 14,3 & 33 & 10,0 & 2,8 & 34,8 \\
\hline $\begin{array}{l}\text { Estabilidade } \\
\text { aeróbia, h }\end{array}$ & 3 & 33,0 & 25,0 & 41,0 & 0 & - & - & - & 5 & 60,0 & 32,0 & 92,0 & 0 & - & - & - \\
\hline $\begin{array}{l}\text { Poder tampão } \\
(\mathrm{mEq} / 100 \mathrm{~g})\end{array}$ & 4 & 41,6 & 39,8 & 42,8 & 4 & 41,7 & 40,9 & 42,9 & 0 & - & - & - & 6 & 34,0 & 21,7 & 40,9 \\
\hline Perdas MS, \% & 0 & - & - & - & 6 & 6,1 & $-0,4$ & 14,1 & 6 & 24,6 & 8,1 & 35,3 & 6 & 6,4 & 5,9 & 7,0 \\
\hline $\begin{array}{l}\text { Perdas gases } \\
(\% \text { MS })\end{array}$ & 0 & - & - & - & 0 & - & - & - & 9 & 17,9 & 8,9 & 31,2 & 7 & 4,7 & 2,4 & 8,5 \\
\hline $\begin{array}{l}\text { Perda efluente } \\
\text { (kg/t MV) }\end{array}$ & 0 & - & - & - & 0 & - & - & - & 9 & 47,2 & 15,1 & 84,9 & 5 & 40,2 & 11,5 & 68,5 \\
\hline $\begin{array}{l}\text { Recuperação } \\
\text { de MS, \% }\end{array}$ & 0 & - & - & - & 0 & - & - & - & 6 & 71,2 & 66,0 & 80,8 & 10 & 92,0 & 87,6 & 96,3 \\
\hline $\begin{array}{l}\text { Recuperação } \\
\text { de MSD, \% }\end{array}$ & 0 & - & - & - & 0 & - & - & - & 3 & 53,0 & 39,8 & 74,3 & 0 & - & - & - \\
\hline $\begin{array}{l}\text { Recuperação } \\
\text { de CNF, \% }\end{array}$ & 0 & - & - & - & 0 & - & - & - & 3 & 35,2 & 25,2 & 53,1 & 0 & - & - & - \\
\hline $\begin{array}{l}\text { Mofos e } \\
\text { leveduras, ufc/g }\end{array}$ & 0 & - & - & - & 0 & - & - & - & 8 & 5,6 & 4,0 & 7,7 & 3 & 3,3 & 2,9 & 3,7 \\
\hline BAL, ufc/g & 0 & - & - & - & 0 & - & - & - & 5 & 2,5 & 2,1 & 3,0 & 3 & 7,3 & 7,2 & 7,3 \\
\hline
\end{tabular}

$\mathrm{N}=$ número de dados que geraram as médias.

$\mathrm{N}-\mathrm{NH}_{3}$ - nitrogênio amoniacal; $\mathrm{BAL}$ - bactérias ácido láticas. 
Tabela 4 - Variações no desempenho de animais recebendo silagens de milho, sorgo, cana-de-açúcar e capim encontradas nos artigos avaliados

\begin{tabular}{|c|c|c|c|c|c|c|c|c|c|c|c|c|c|c|c|c|}
\hline \multirow[b]{2}{*}{ Parâmetro } & \multicolumn{4}{|c|}{ Silagem de milho } & \multicolumn{4}{|c|}{ Silagem de sorgo } & \multicolumn{4}{|c|}{ Silagem de cana-de-açúcar } & \multicolumn{4}{|c|}{ Silagem de capim } \\
\hline & $\mathrm{n}$ & Média & Mín & Máx & $\mathrm{n}$ & Média & Mín & Máx & $\mathrm{n}$ & Média & Mín & Máx & $\mathrm{n}$ & Média & Mín & Máx \\
\hline CMS, \% PV & 7 & 2,3 & 2,0 & 2,8 & 4 & 1,9 & 1,6 & 2,1 & 4 & 3,1 & 2,2 & 3,9 & 9 & 1,9 & 1,4 & 2,5 \\
\hline CMSD, \% PV & 2 & 1,4 & 1,4 & 1,5 & 2 & 0,9 & 0,9 & 0,9 & 3 & 1,3 & 1,3 & 1,3 & 2 & 0,8 & 0,7 & 0,8 \\
\hline CNDT, \%PV & 2 & 1,4 & 1,4 & 1,5 & 2 & 0,9 & 0,8 & 0,9 & 0 & - & - & - & 2 & 0,7 & 0,6 & 0,7 \\
\hline CFDN, \% PV & 5 & 0,9 & 0,7 & 1,1 & 2 & 0,8 & 0,8 & 0,8 & 3 & 0,7 & 0,7 & 0,7 & 0 & - & - & - \\
\hline $\begin{array}{l}\text { GP bovinos } \\
(\mathrm{kg} / \mathrm{d})\end{array}$ & 2 & 1,2 & 1,2 & 1,3 & 0 & - & - & - & 2 & 1,1 & 0,9 & 1,2 & 2 & 1,0 & 1,0 & 1,1 \\
\hline $\begin{array}{l}\text { GP ovinos } \\
(\mathrm{kg} / \mathrm{d})\end{array}$ & 0 & - & - & - & 0 & - & - & - & 2 & 0,2 & 0,2 & 0,2 & 0 & - & - & - \\
\hline $\mathrm{CA}$ & 0 & - & - & - & 0 & - & - & - & 4 & 8,3 & 7,7 & 9,4 & 2 & 8,2 & 8,1 & 8,2 \\
\hline DAMS, $\%$ & 7 & 61,3 & 54,8 & 64,6 & 2 & 60,6 & 60,1 & 61,1 & 5 & 66,4 & 62,5 & 72,1 & 7 & 55,0 & 48,4 & 66,4 \\
\hline DAFDN, \% & 7 & 45,2 & 35,2 & 56,9 & 2 & 51,4 & 50,4 & 52,3 & 5 & 56,2 & 50,7 & 64,9 & 4 & 55,2 & 48,0 & 62,8 \\
\hline DIVMS, \% & 3 & 70,3 & 68,3 & 71,6 & 15 & 59,5 & 55,9 & 62,8 & 22 & 48,0 & 34,6 & 60,0 & 22 & 53,6 & 32,5 & 65,3 \\
\hline
\end{tabular}

$\mathrm{N}$ = número de dados que geraram as médias.

CMS - consumo de MS; CMSD - consumo de MS digestível; CNDT - consumo de nutrientes digestíveis totais; CFDN - consumo de FDN; GP - ganho de peso diário; CA - conversão alimentar; DAMS - digestibilidade aparente da MS; DAFDN - digestibilidade aparente do FDN; DIVMS - digestibilidade in vitro da MS.

mostraram aumento nos teores de proteína bruta. $\mathrm{O} \mathrm{pH}$ das silagens aditivadas foi reduzido em relação à silagem controle em $33,3 \%$ dos dados avaliados, e $40 \%$ dos resultados apontaram para elevação da DIVMS das silagens inoculadas (Figura 2).

Em média, as silagens de milho inoculadas apresentaram aumentos de $0,65 \%$ no teor de PB e de $1,8 \%$ no valor de DIVMS. Os teores de celulose, hemicelulose e FDN reduziram em 2,$48 ; 8,0$ e 3,52\%, respectivamente, e o $\mathrm{pH}$ reduziu em $1,07 \%$ em relação às silagens controle (Figura 3 ). Quando analisados os resultados obtidos somente com respostas favoráveis, os aumentos nos teores de $\mathrm{PB}$ e na DIVMS foram de 6,46 e 4,49\%, respectivamente. O teor de celulose reduziu em $12 \%$, o de hemicelulose em $7,45 \%$, o de FDN em $15,85 \%$ e o $\mathrm{pH}$ reduziu em $3,22 \%$.
Os conjunto de resultados encontrados sugere o possível efeito de enzimas fibrolíticas, reduzindo a porção fibrosa da silagem tratada e, consequentemente, a maior concentração da fração protéica na MS. Entretanto, segundo Adesogan (2005), a atividade das enzimas celulase e hemicelulase é insuficiente para hidrólise completa da parede celular de gramíneas tropicais.

Estudos recentes mostraram que algumas bactérias heterofermentativas (Lactobacillus buchneri, Lactobacillus brevis) produzem ferulato-esterases, enzimas que aumentam a degradação da parede celular, liberando mais carboidratos solúveis para a fermentação ou utilização pelas bactérias do rúmen (Nserekoetal., 2008). No entanto, nos trabalhos avaliados para silagens de milho foram utilizadas apenas bactérias homofermentativas, de acordo com o relato dos autores.

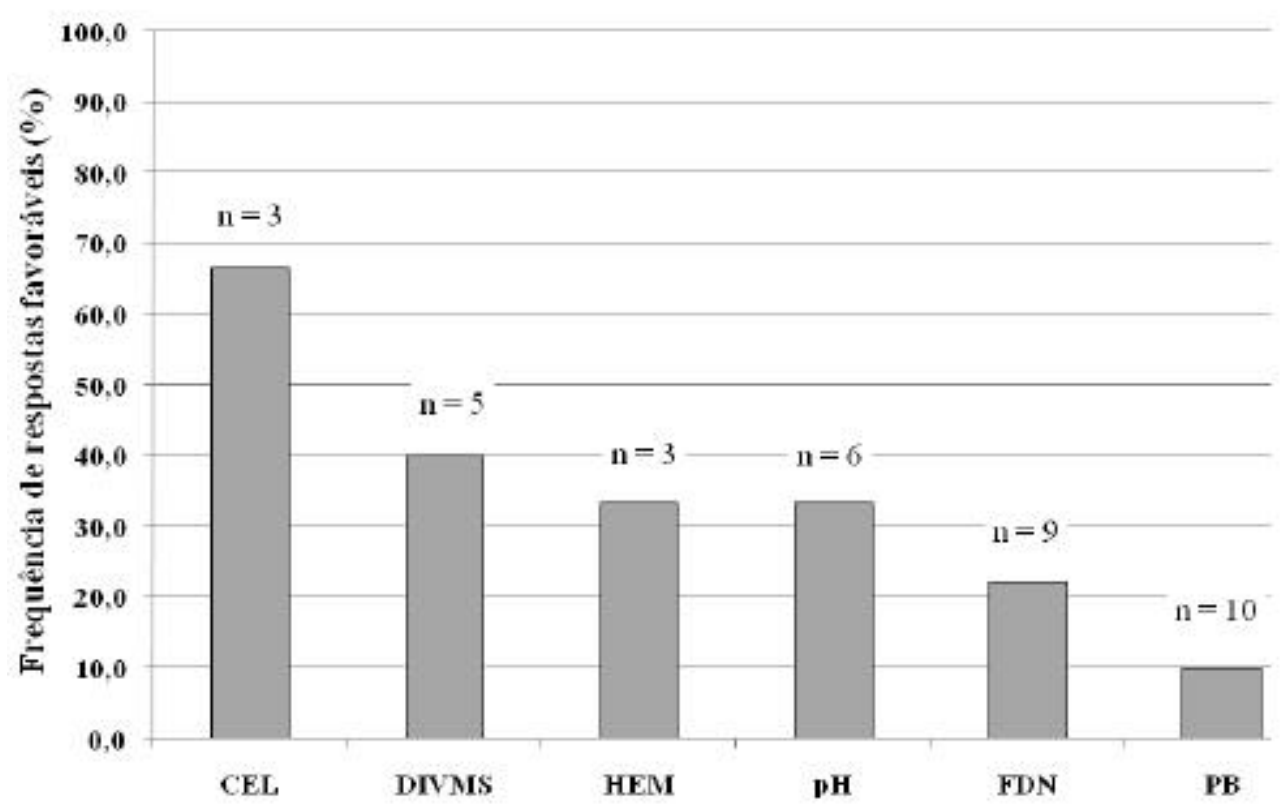

Figura 2 - Frequência de respostas favoráveis em silagens de milho aditivadas com inoculantes microbiológicos 


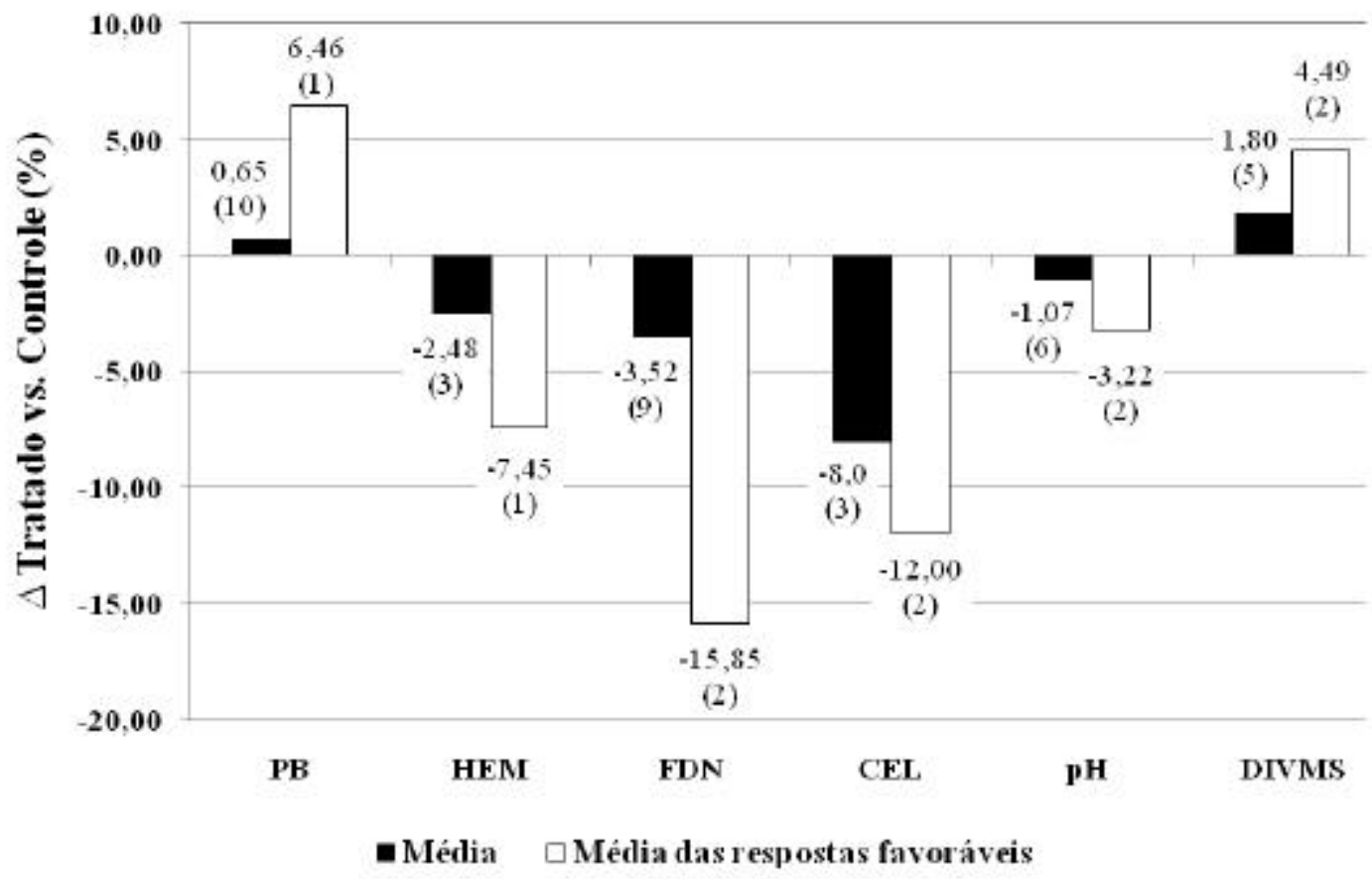

Figura 3 - Média geral e média dos resultados contendo respostas favoráveis nos valores do diferencial de resposta $(\Delta)$ entre as silagens de milho aditivadas com inoculantes microbiológicos em relação às silagens controle.

\section{Silagem de sorgo}

Os seis trabalhos contendo silagens de sorgo incluídos nesta revisão (Pedroso et al., 2000; Rodrigues et al., 2002a; Rodrigues et al., 2002b; Silva et al., 2005; Silva et al., 2006; Vieira et al., 2006), utilizaram bactérias homofermentativas, e em todos os casos foram utilizadas cepas de mais de uma espécie. Em cinco trabalhos, enzimas foram associadas às bactérias e utilizadas em alguns tratamentos e as doses de aplicação dos inoculantes variaram entre $8 \times 10^{5}$ e 9x10 10 ufc/g de forragem.

A Figura 4 ilustra a baixa frequência de respostas favoráveis à utilização de aditivos microbianos em silagens de sorgo.

As maiores magnitudes de respostas ( $\ddot{A})$ favoráveis foram encontradas para os teores de proteína bruta, hemicelulose e para o valor de digestibilidade in vitro da MS (Figura 5). Provavelmente, o maior teor de PB das silagens tratadas em relação ao controle se deve ao efeito de concentração, ou seja, a redução no conteúdo de outras frações pode ter sido maior que na fração PB. O menor conteúdo de hemicelulose das silagens tratadas em relação ao controle pode ter sido devido ao resultado da ação de enzimas associadas às bactérias. Este efeito, entretanto, não foi traduzido em redução da fração FDN. Maior teor de PB e menor teor de hemicelulose podem ter sido os responsáveis pela maior DIVMS. O maior teor de etanol nas silagens tratadas, embora não considerado favorável por representar perdas de MS, também pode ter contribuído para aumentar a digestibilidade in vitro da MS (Chalupa et al., 1964).

De maneira geral, não houve vantagem expressiva na utilização de bactérias homofermentativas no processo de ensilagem de sorgo devido a baixa frequência de respostas favoráveis. As silagens decorrentes dos artigos incluídos nesta revisão, inclusive aquelas que não receberam inoculantes (controle), apresentaram qualidade satisfatória (Tabelas 2, 3 e 4), sendo este fato importante para justificar a ausência de respostas favoráveis na maioria das variáveis estudadas (Figura 4).

Silagem de cana-de-açúcar

Dos trabalhos publicados na última década envolvendo o uso de aditivos microbianos em silagens de cana-deaçúcar, 14 foramconsiderados neste levantamento. Destes, 12 utilizaram L. buchneri (heterofermentativa) (Freitas et al., 2006a; Pedroso et al., 2006; Pedroso et al., 2007; Siqueira et al., 2007a; Siqueira et al., 2007b; Schmidt et al., 2007a; Schmidt et al., 2007b; Ávila et al., 2008; Mendes et al., 2008a; Mendes et al., 2008b; Santos et al. 2009), seis utilizaram bactérias homofermentativas (Freitas et al., 2006a; Ferreira et al., 2007; Pedroso et al., 2007; Schmidt et al., 2007a; Schmidt et al., 2007b; Castro Neto et al., 2008) e três utilizaram associações de bactérias heterofermentativas e 


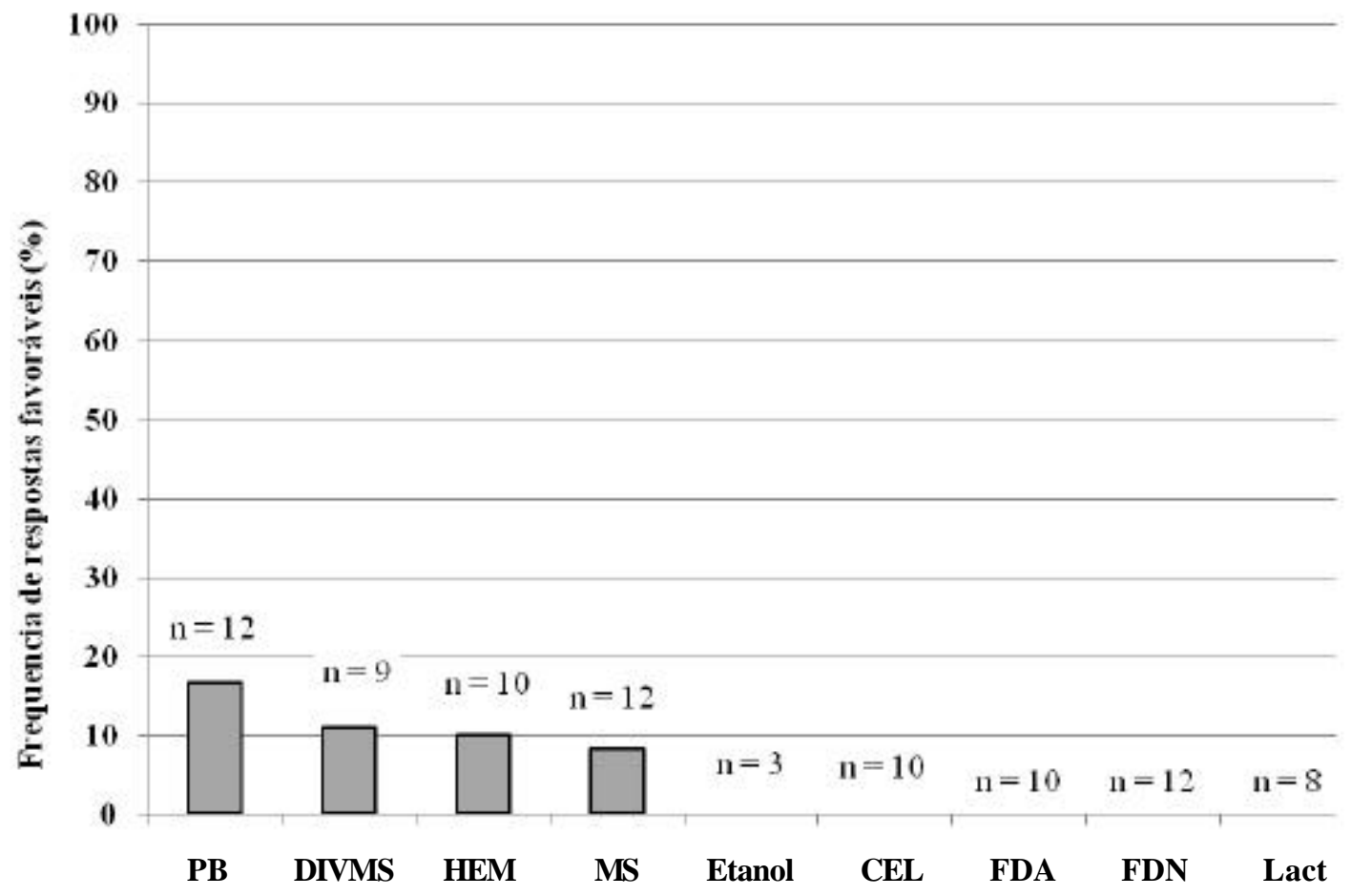

Figura 4 - Frequência de respostas favoráveis em silagens de sorgo aditivadas com inoculantes microbiológicos.

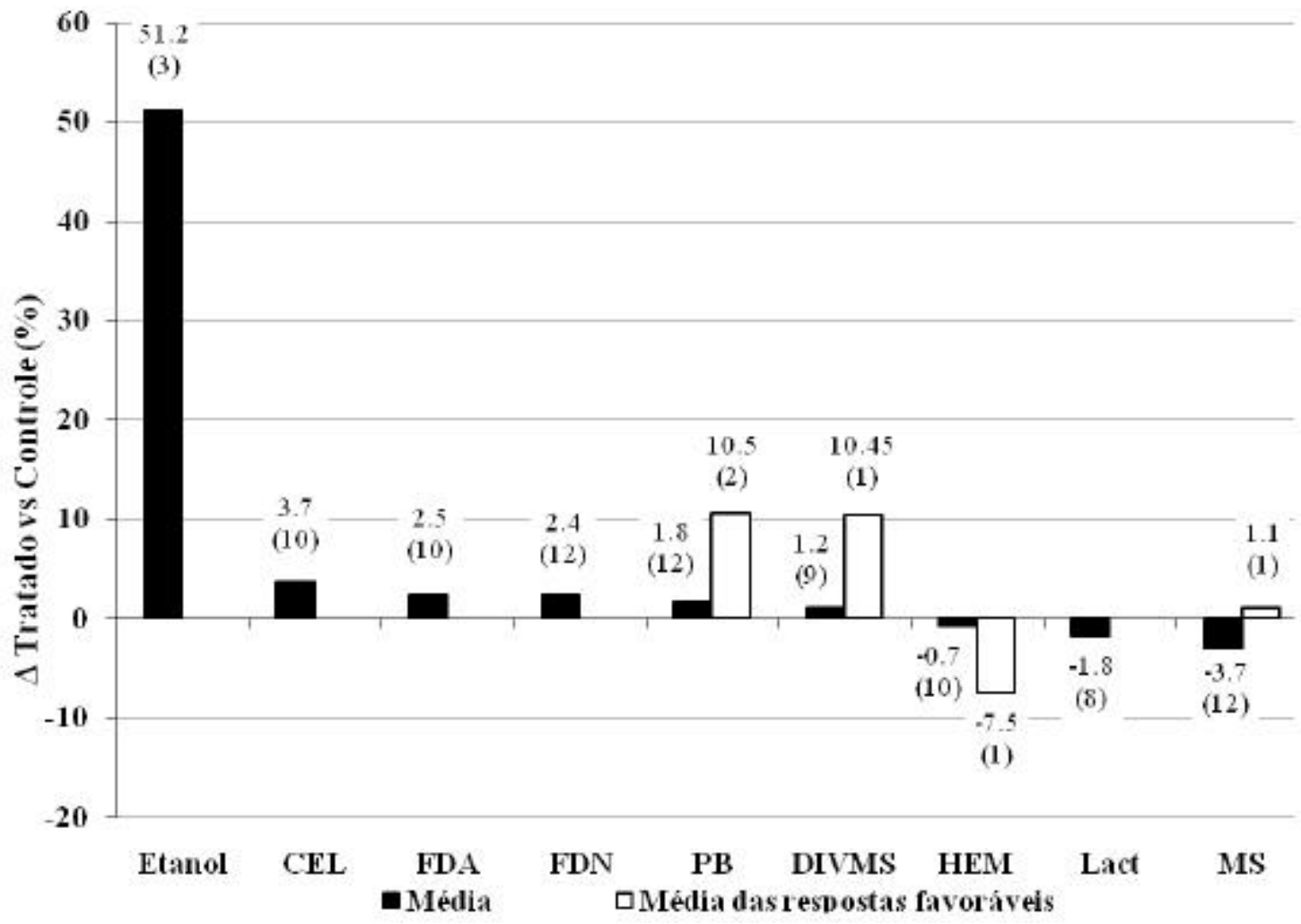

Figura 5 - Média geral e média dos resultados contendo respostas favoráveis nos valores do diferencial de resposta (") entre as silagens de sorgo aditivadas com inoculantes microbiológicos em relação às silagens controle. 
homofermentativas (Siqueira et al., 2007a; Siqueira et al., 2007b; Sousa et al., 2008). Os vetores (+, -, 0) de algumas variáveis ocorreram em sentidos opostos para os diferentes grupos de bactérias (Figuras 6 e 7), e sendo assim, a exploração dos dados ocorreu separadamente para cada grupo de microrganismos.
As doses de aplicação dos inoculantes à base de bactérias homofermentativas variaramentre $1,5 \times 10^{5}$ e $1 \times 10^{6}$ ufc/g de forragem, de heterofermentativas de $2,5 \times 10^{4}$ a $3,64 \times 10^{5} \mathrm{ufc} / \mathrm{g}$ de forragem, e para os aditivos contendo bactérias heterofermentativas e homofermentativas a contagem foi de $1,5 \times 10^{5} \mathrm{ufc} / \mathrm{g}$ de forragem.

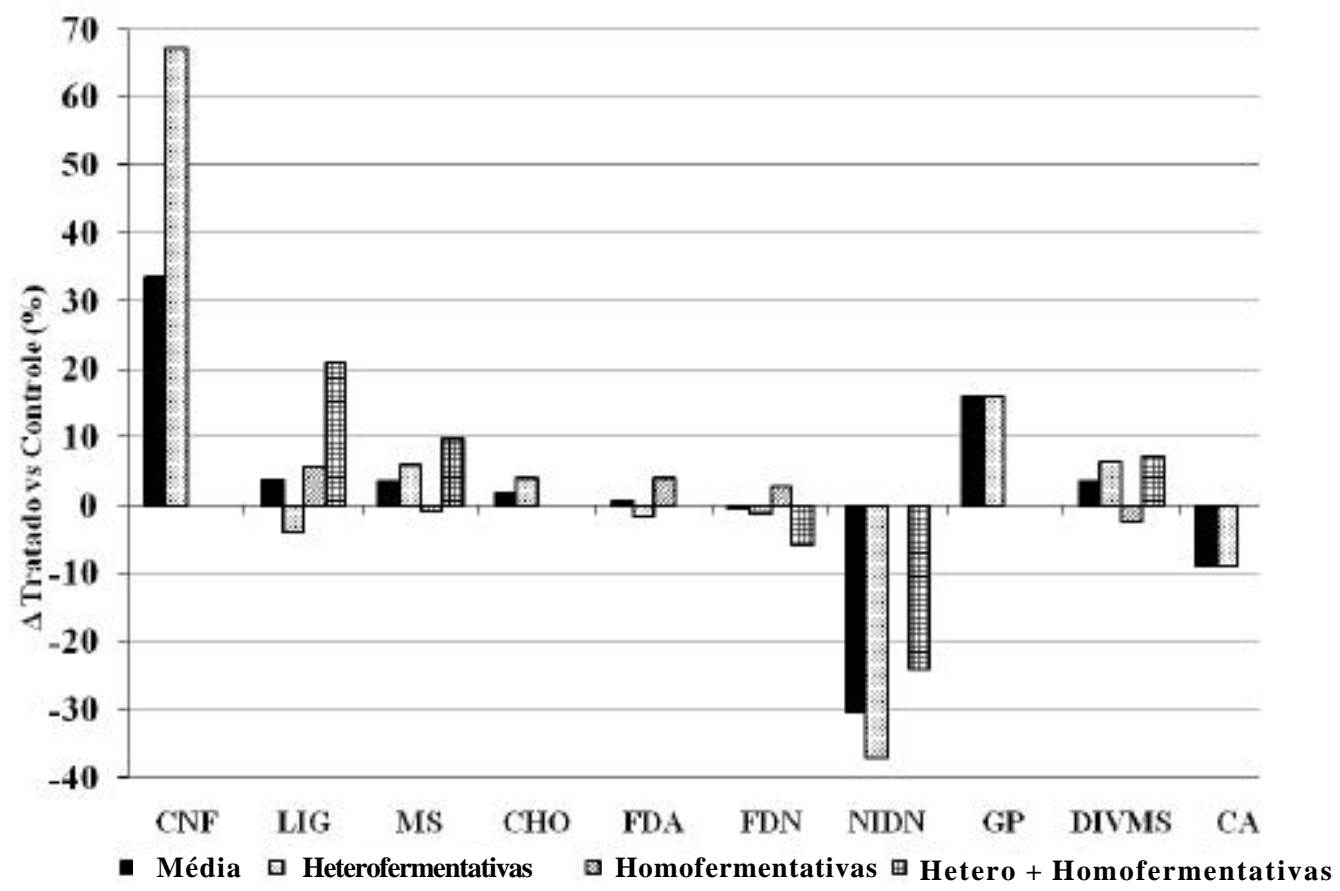

Figura 6 - Média dos diferenciais de resposta para variáveis de valor nutritivo e de desempenho de animais entre silagens de cana-de-açúcar tratadas com inoculantes e as silagens controle.

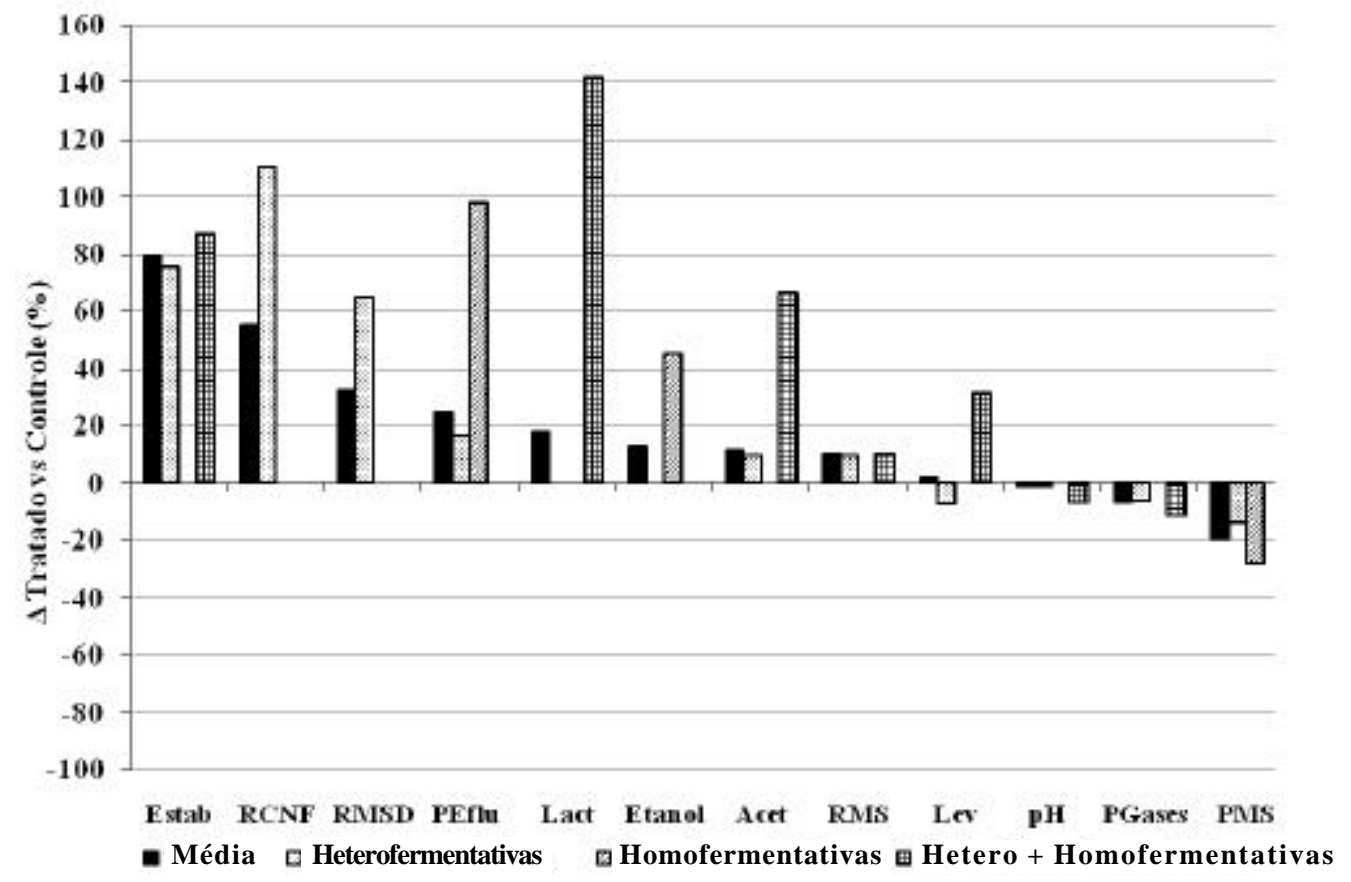

Figura 7 - Média dos diferenciais de resposta de parâmetros fermentativos entre silagens de cana-de-açúcar tratadas com inoculantes e as silagens controle. 
A utilização de L. buchneri resultou em $100 \%$ de respostas favoráveis para as variáveis teor de carboidratos não fibroso (CNF), teor de nitrogênio insolúvel em detergente neutro, recuperação de $\mathrm{CNF}$, recuperação de MS digestível e estabilidade aeróbia (Figuras 8 e 9), porém, o número de dados encontrados para tais variáveis $(n=1$ ou 2) foi considerado reduzido e insuficiente para o estabelecimento de conclusões definitivas. Variáveis compostas por maior número de observações, como teor de MS, teor de FDA, teor de FDN, digestibilidade in vitro da MS e pH, apresentaram frequências de respostas favoráveis variando entre $15 \%$ e $40 \%$ (Figura $8,9,10$ e 11 ).

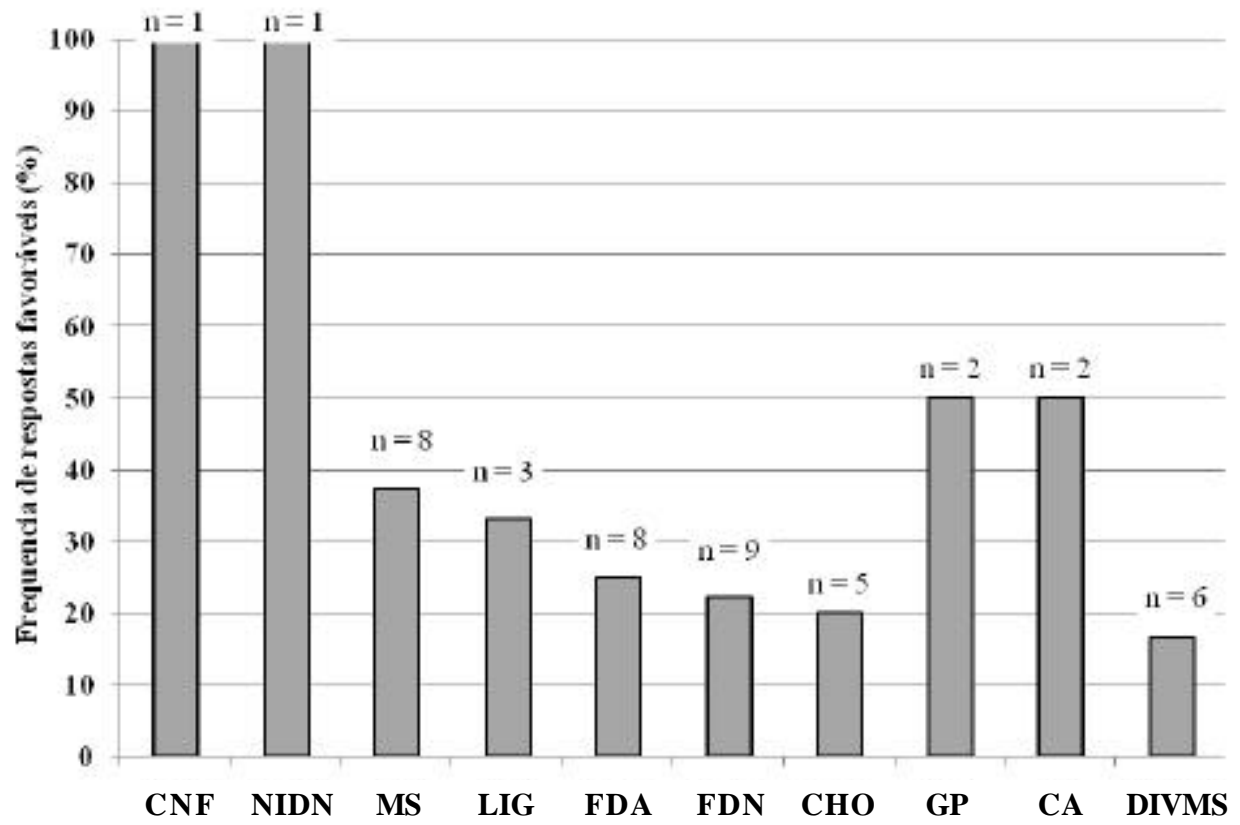

Figura 8 - Frequência de respostas favoráveis em silagens de cana-de-açúcar aditivadas com inoculantes microbiológicos à base de bactérias heterofermentativas.

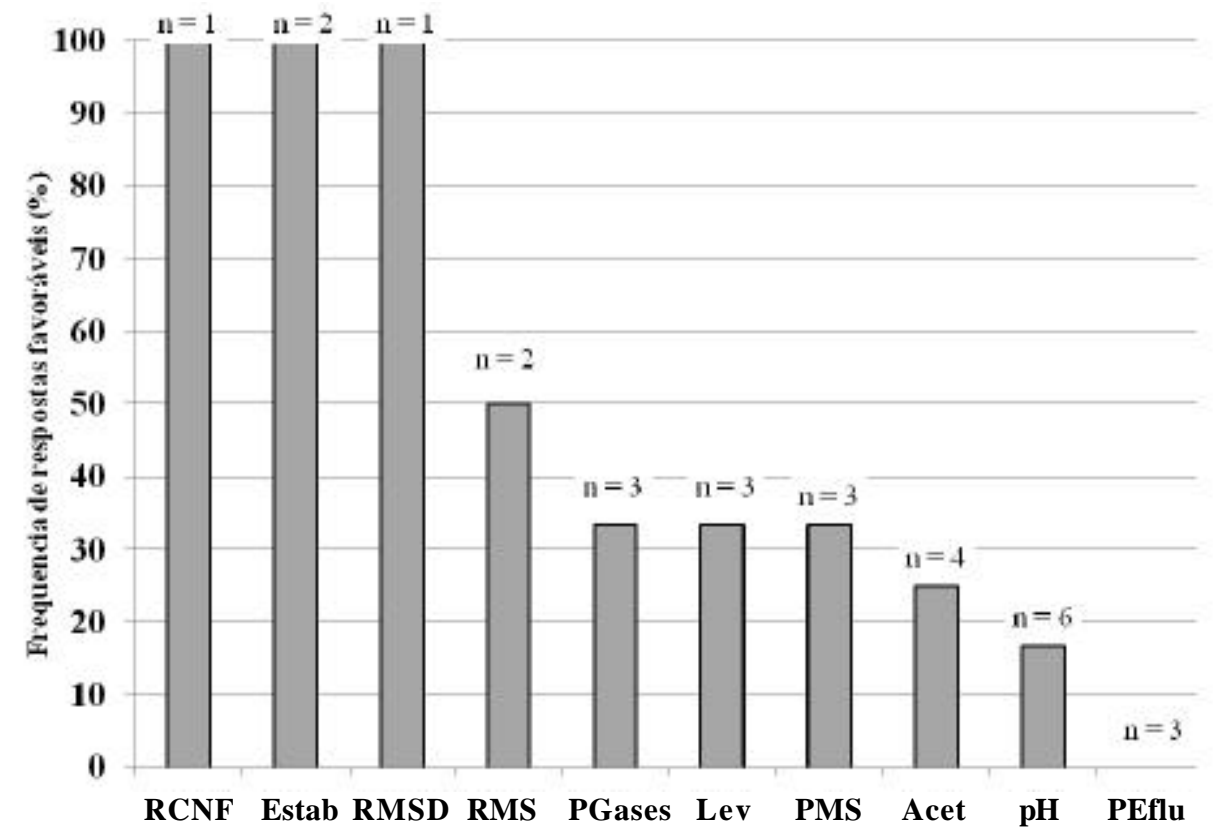

Figura 9 - Frequência de respostas favoráveis em silagens de cana-de-açúcar aditivadas com inoculantes microbiológicos à base de bactérias heterofermentativas. 


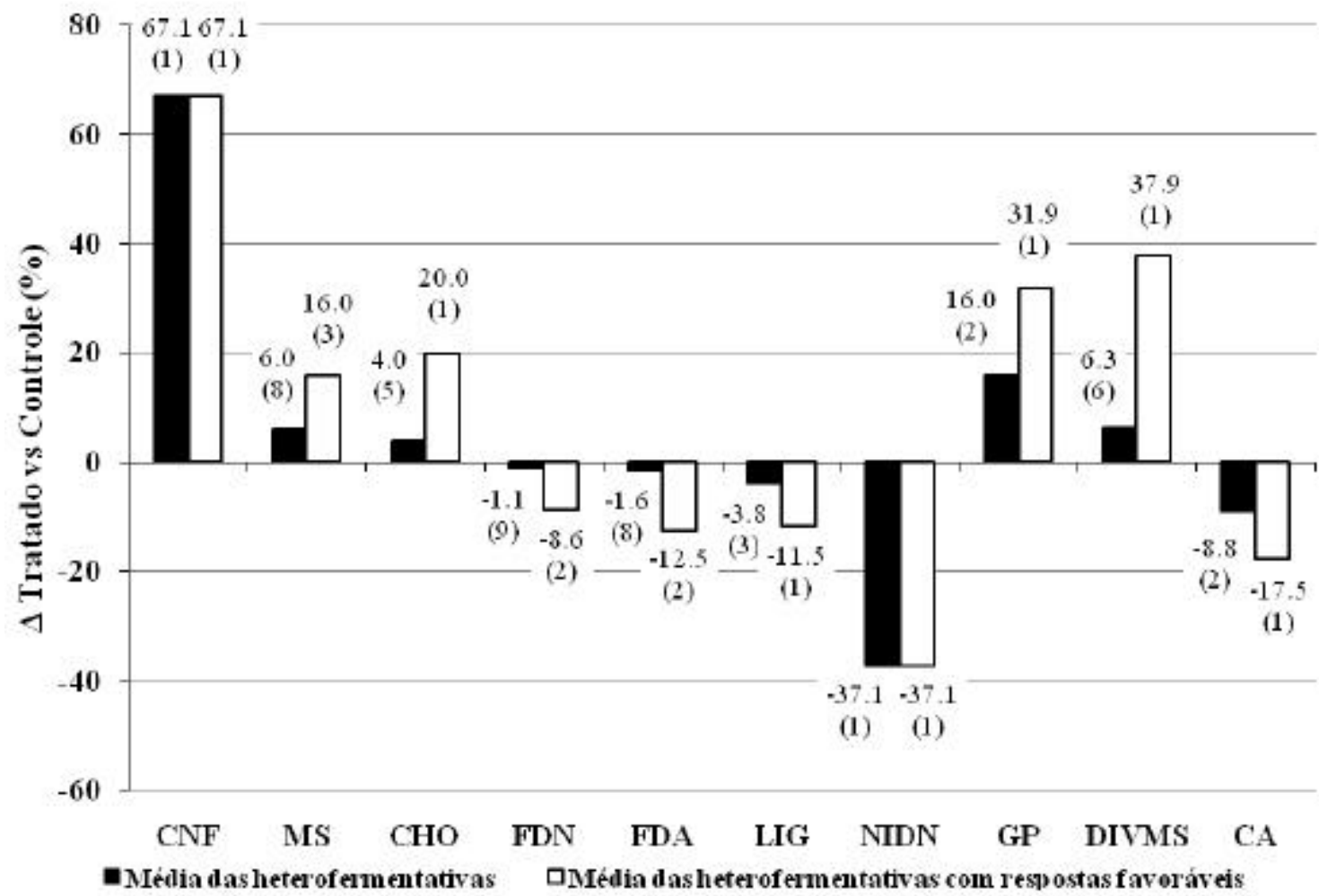

Figura 10 - Média geral e média dos resultados contendo respostas favoráveis nos valores do diferencial de resposta entre as silagens de cana-de-açúcar aditivadas com inoculantes microbiológicos à base de bactérias heterofermentativas e as silagens controle.

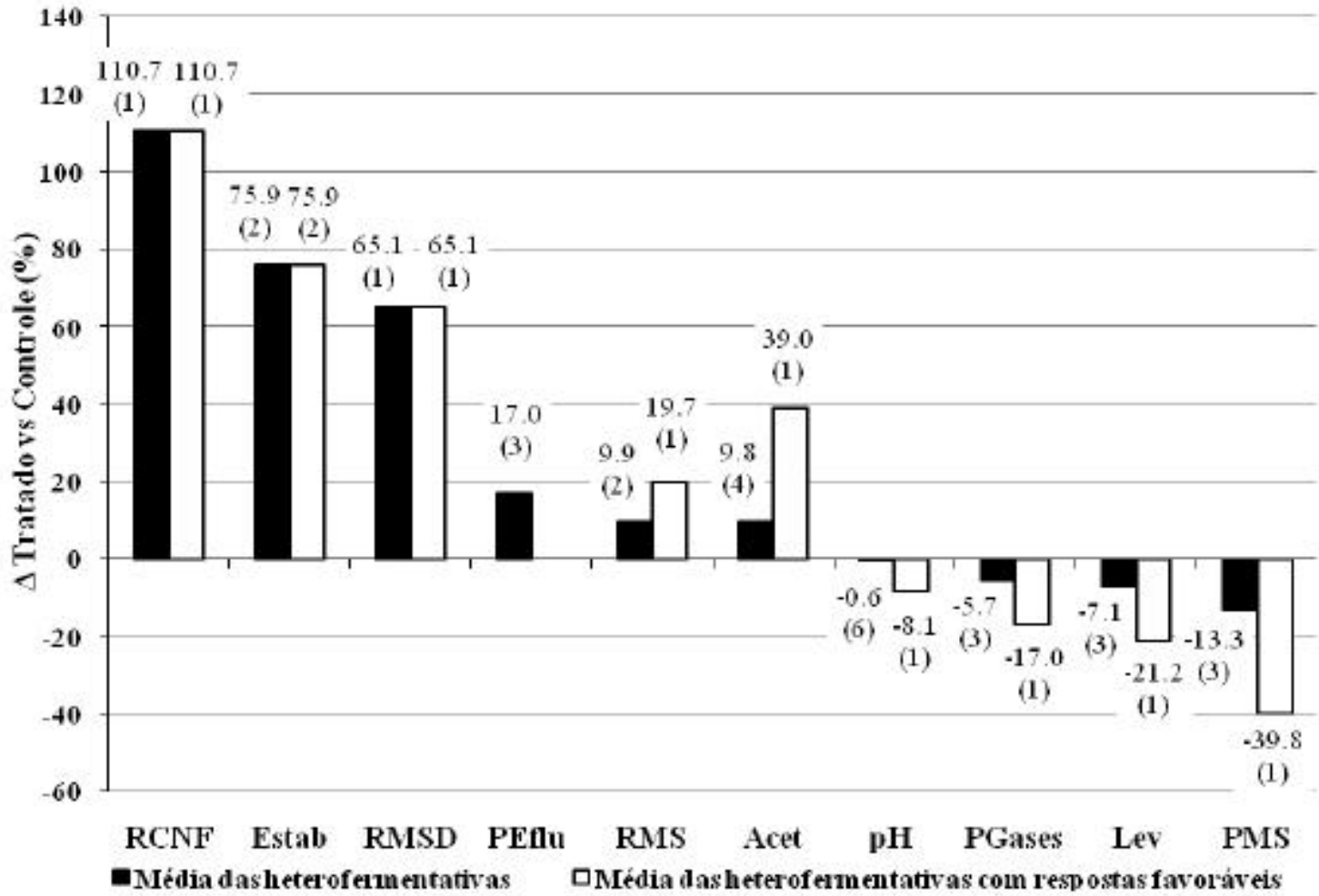

Figura 11 - Média geral e média dos resultados contendo respostas favoráveis nos valores do diferencial de resposta entre as silagens de cana-de-açúcar aditivadas com inoculantes microbiológicos à base de bactérias heterofermentativas e as silagens controle. 
A população de leveduras foi reduzida significativamente em um de três trabalhos (33\%; Figura 9). Um artigo demonstrou aumento na concentração de ácido acético num total de quatro trabalhos avaliados $(25 \%$, Figura 9). A produção de ácido acético porL. buchneri via metabolização de ácido lático tem sido descrita na literatura (Oude Elferink et al., 2001). O 1,2-propanediol, também formado ao longo desta rota, pode ser convertido, por outros microrganismos, à ácido propiônico, que apresenta efeito anti-fúngico documentado (Driehuis et al., 1999). Além disso, outras substâncias anti-microbianas como bacteriocinas também podem ser produzidas por L. buchneri (Yildirim, 2001).

Por outro lado, o teor de etanol não foi reduzido significativamente em nenhum dos trabalhos incluídos neste levantamento. A possível redução na produção de etanol por leveduras pode ter sido mascarada em parte pelo estímulo à produção de etanol causado pelo próprio L. buchneri (Kleinschmit \& Kung, 2006; Oude Elferink et al., 2001), embora em quantidade muito reduzida. Esse mesmo padrão de resposta já havia sido também descrito para silagens de milho (Kleinschmit \& Kung, 2006) em situação análoga. Outra explicação se refere a dificuldade metodológica para a recuperação precisa do etanol sintetizado na massa ensilada. Em revisão, Jobim et al. (2007) relataram que o teor de etanol descrito em silagens poderia representar pequena fração do etanol efetivamente produzido, induzindo à distorções na interpretação da eficiência de estratégias de controle de etanol em silagens.

No caso das bactérias homofermentativas, apenas um único trabalho dentre dois trabalhos encontrados mostrou redução nas perdas de MS. Não houve outras respostas favoráveis (Figura 12). Por outro lado, a utilização destes microrganismos estimulou a perda por efluentes e a produção de etanol (Figura 13), entretanto, naquele caso, a maior produção de etanol não foi traduzida em maior perda de MS.

Da mesma forma como ocorrido para a utilização de $L$. buchneri, a utilização de bactérias heterofermentativas associadas à homofermentativas resultou em elevada frequência de resposta favorável para diversas variáveis (Figuras 14, 15 e 16), embora os dados sejam escassos e inconclusivos. A experiência ocorrida com a associação de microrganismos em silagens fora do Brasil vem mostrando histórico positivo. A hipótese dessa combinação seria a de intencionalmente selecionar cepas eficazes para o otimização conjunta de respostas em fermentação e de estabilidade aeróbia na massa, que não seria alcançada com as estratégias convencionais de exploração exclusiva de cada grupo desses microrganismos (Driehuis et al., 2001). Embora a associação de microrganismos resulte, em geral, em elevação significativa do custo do aditivo, também representa uma oportunidade contemporânea e sustentável de se atingir

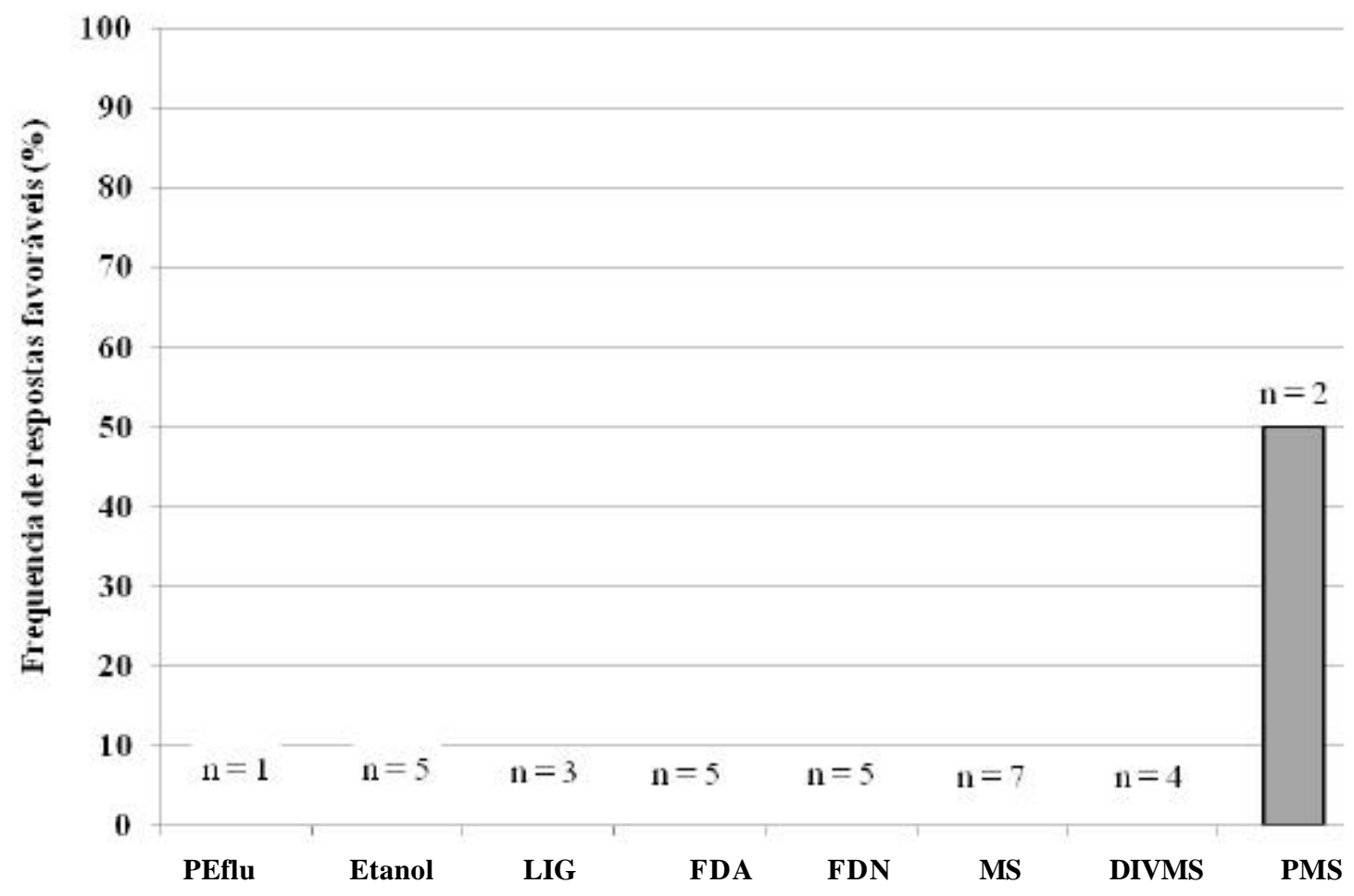

Figura 12 - Frequência de respostas favoráveis em silagens de cana-de-açúcar aditivadas com inoculantes microbiológicos à base de bactérias homofermentativas. 


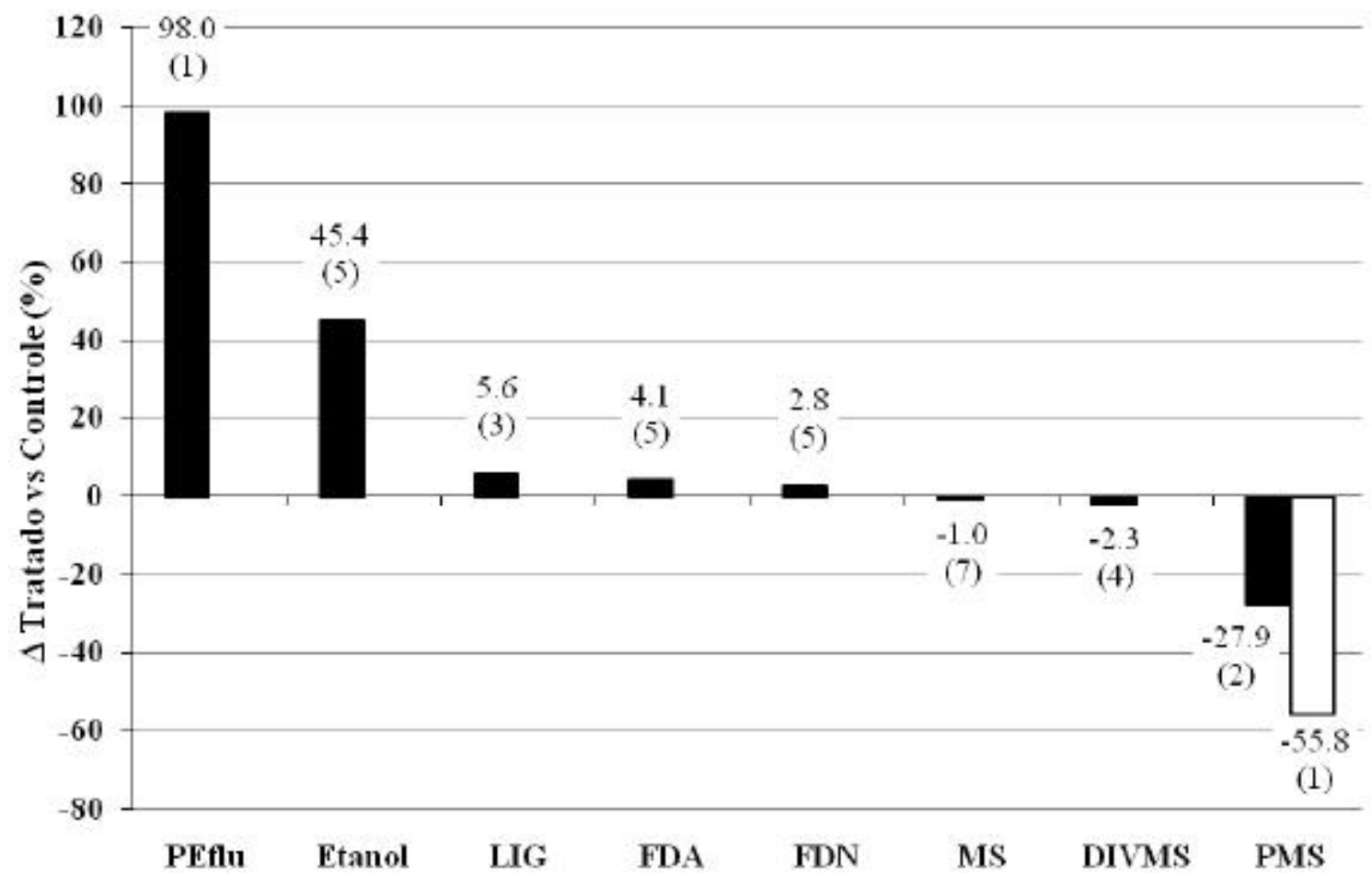

-Média das hom of ermentativas aMédia das hom of ermentativas coun respostas favoráveis

Figura 13 - Média geral e média dos resultados com respostas favoráveis nos valores do diferencial de resposta entre as silagens de canade-açúcar aditivadas com inoculantes microbiológicos à base de bactérias homofermentativas e as silagens controle.

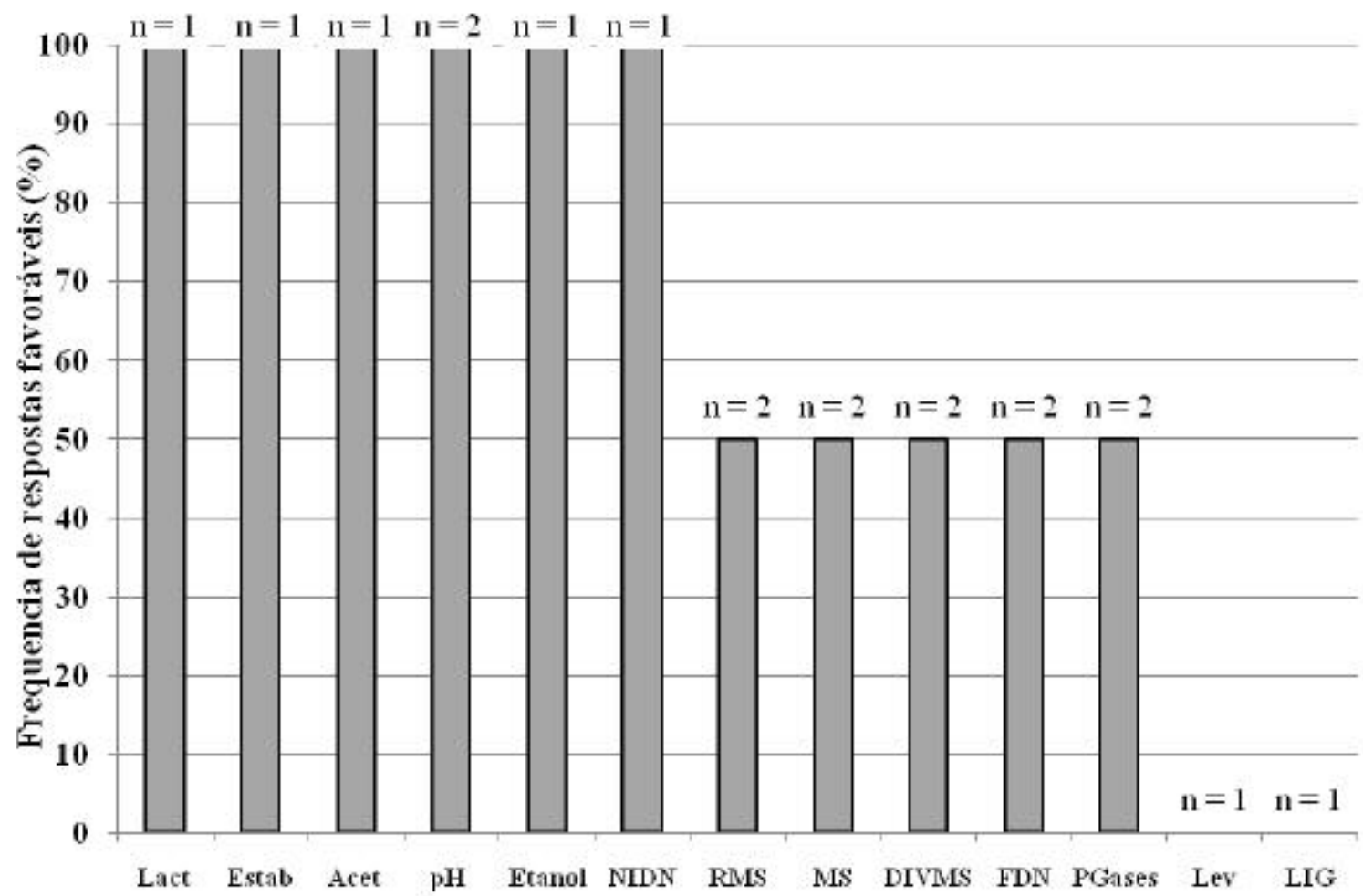

Figura 14 - Frequência de respostas favoráveis em silagens de cana-de-açúcar aditivadas com inoculantes microbiológicos contendo associação de bactérias hetero e homofermentativas. 


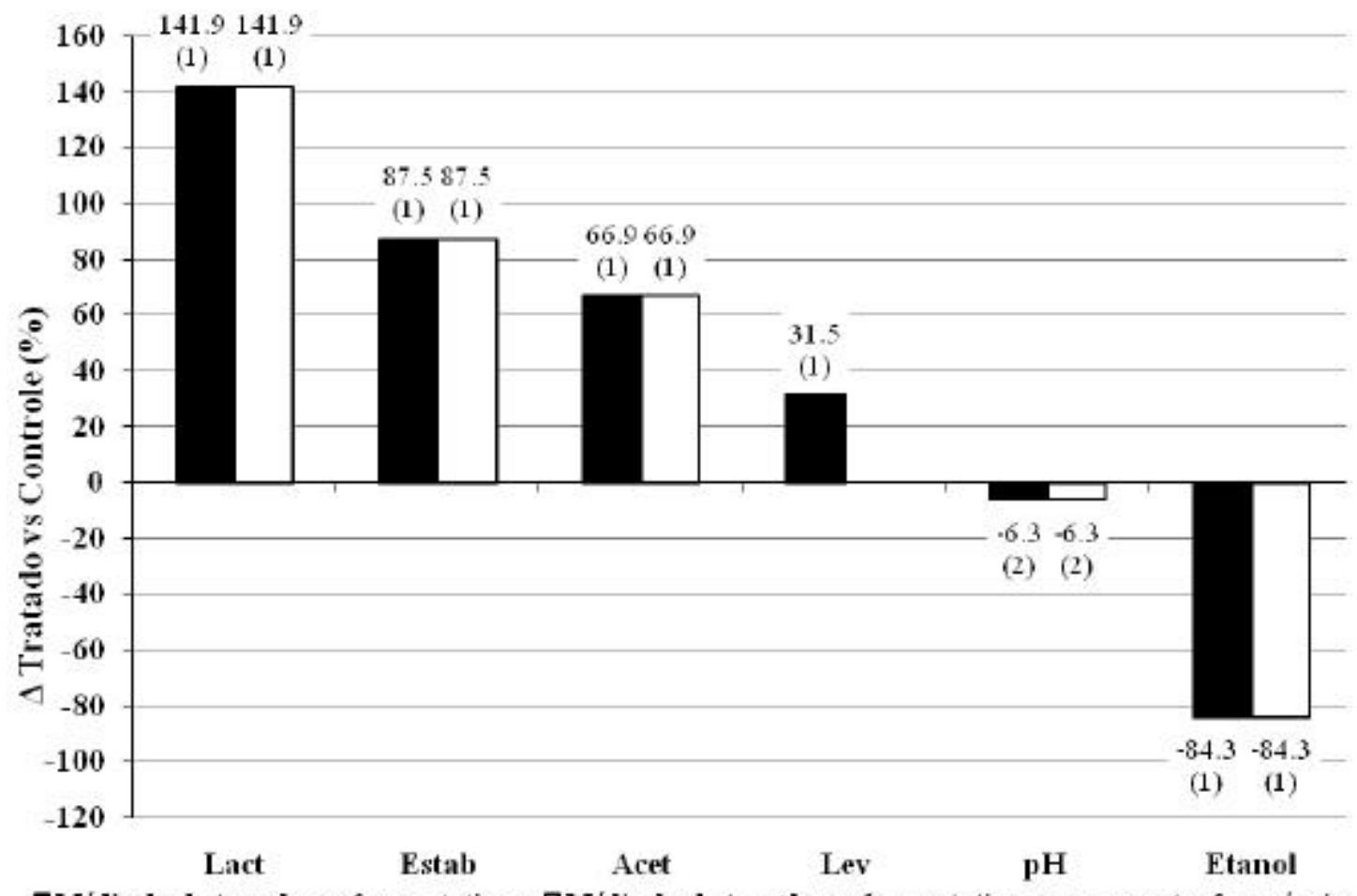

Figura 15 - Média geral e média dos resultados contendo respostas favoráveis nos valores do diferencial de resposta entre as silagens de cana-de-açúcar aditivadas com inoculantes microbiológicos contendo a associação de bactérias hetero e homofermentativas e as silagens controle.

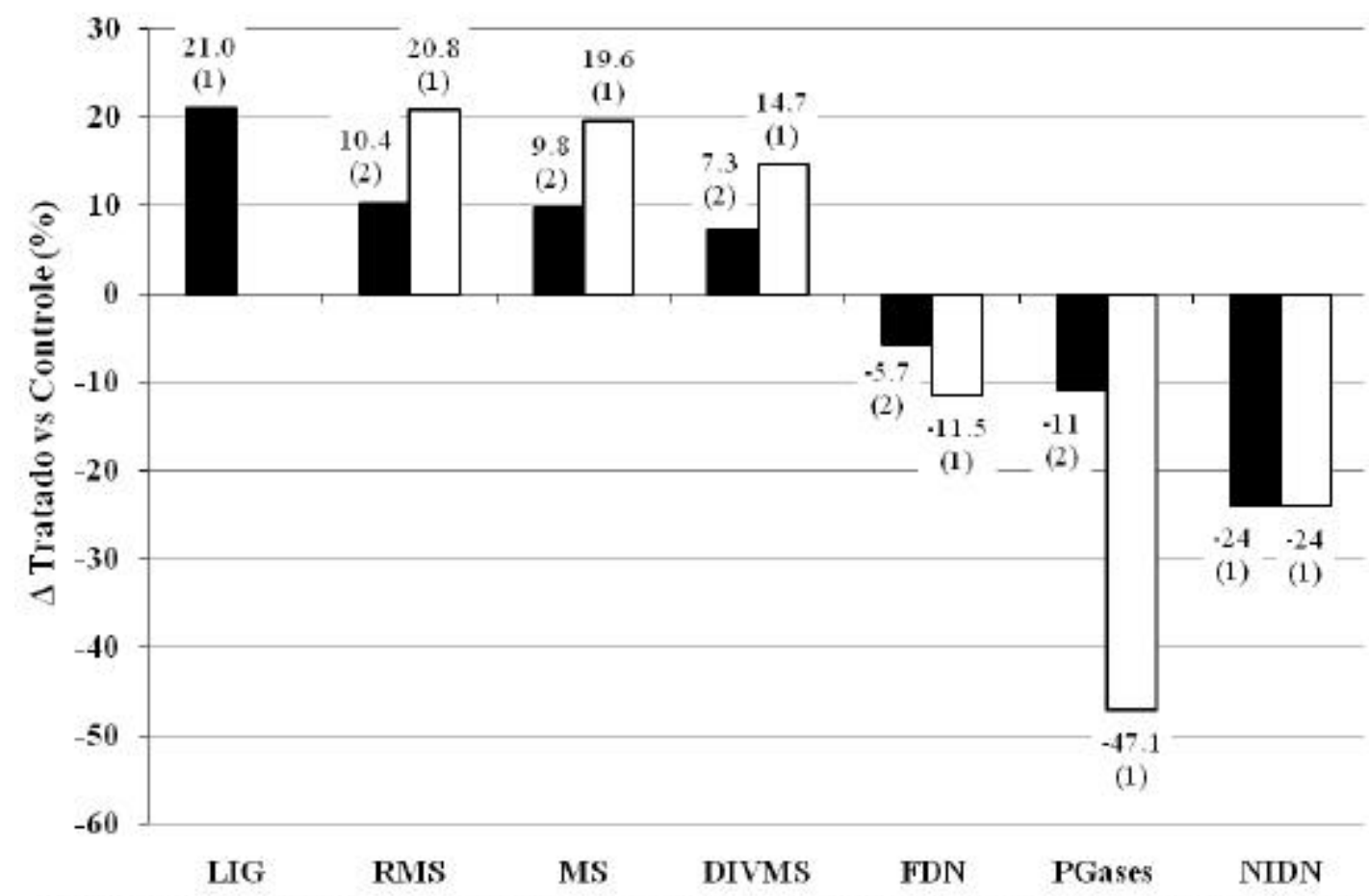

Figura 16 - Média geral e média dos resultados contendo respostas favoráveis nos valores do diferencial de resposta entre as silagens de cana-de-açúcar aditivadas com inoculantes microbiológicos à base de bactérias hetero e homofermentativas em relação às silagens controle. 
benefícios da simbiose positiva dessa combinação. O desenvolvimento de produtos comerciais nessa linha exige estudos básicos e aplicados da viabilidade conjunta desses microrganismos, atividade biológica e atividade enzimática dessas associações desafiadas pelas condições comuns de ocorrência do processo de ensilagem à campo. A modesta exploração dessa possibilidade em experimentos de ensilagem na país remete à necessidade de intensificação de esforços da pesquisa para que se possa criar consenso sobre a frequência e magnitude de respostas dessa aplicação. As análises apresentadas nas Figuras 15 e 16 sugerem respostas expressivas resultantes dessa combinação, entretanto, em diversas variáveis a média é composta por um único resultado publicado.

\section{Silagens de capins tropicais}

Os 15 estudos contendo silagens de capins inoculadas com aditivos microbianos compreenderam cinco trabalhos com Brachiaria brizantha cv. Marandu (Andrade \& Melotti, 2003; Bergamaschine et al., 2006; Bernardes et al., 2007; Bernardes et al., 2008; Ribeiro et al., 2009), quatro com Panicum maximumcv.Tanzânia (Coan et al., 2005; Loures et al., 2005; Paziani et al., 2006a; Paziani et al., 2006b), cinco trabalhos com Pennisetum purpureum cv. Napier (Rodrigues et al., 2001; Rodrigues et al., 2003; Andrade \& Melotti, 2004; Patrizi et al., 2004; Pereira et al., 2007) e um estudo com Cynodon cv. Tifton 85 (Castro et al., 2006).

Do total de trabalhos, 12 avaliaram inoculantes exclusivamente à base de bactérias homofermentativas, dois trabalhos contendo tanto bactérias heterofermentativas como a associação de hetero mais homofermentativas (Bernardes et al. 2007, 2008), além de um outro artigo que avaliou tratamentos contendo bactérias homofermentativas isoladas ou a combinação de hetero mais homofermentativas (Patrizi et al., 2004). Adicionalmente, dos 15 trabalhos avaliados, sete apresentaram tratamentos que continham enzimas.

As doses de aplicação dos inoculantes à base de bactérias homofermentativas variaram entre $1 \times 10^{5}$ e $1 \times 10^{11}$ ufc/g de forragem, no caso das heterofermentativas foi de $5 \times 10^{4} \mathrm{ufc} / \mathrm{g}$ de forragem, e para a presença de ambas foi de $1,5 \times 10^{5} \mathrm{ufc} / \mathrm{g}$ de forragem.

A Figura 17 apresenta as médias dos diferenciais de resposta entre silagens de capins tratadas com inoculantes e silagens controle. Reconhecendo que bactérias homo e heterofermentativas podem apresentam padrões de respostas não coincidentes, buscou-se as exploração dos resultados específicos para cada grupo de microrganismos, conforme apresentado das Figuras 19, 20 e 21.
A Figura 18 apresenta a freqüência de respostas favoráveis observadas para as silagens de capins tratadas com bactérias heterofermentativas, homofermentativas ou sua combinação.

As bactérias apresentaram diferentes perfis de ação sobre os parâmetros avaliados. As silagens inoculadas com as bactérias homofermentativas apresentaram redução no pH em 37,5\% dos resultados avaliados, comprovando a eficácia do ácido lático em diminuir o $\mathrm{pH}$ na ensilagem. Apesar do número reduzido de trabalhos com silagens de capins inoculadas com bactérias heterofermentativas, quando ocorreram, as respostas positivas foram encontradas para as variáveis MS (50\%), PB (100\%) e produção de efluente (100\%). Da mesma forma, nas silagens inoculadas com a combinação de bactérias hetero mais homofermentativas as respostas positivas foram encontradas para as variáveis recuperação de MS (50\%), FDA (50\%), MS (33,3\%), PB (50\%) e produção de efluente $(100 \%)$.

Na Figura 19 são apresentados os valores do diferencial de resposta (tratado versus controle) das silagens de capins aditivadas com bactérias homofermentativas.

Em média, os teores de NIDA, PB, MS, HEM, CEL, e CHO aumentaram em 8,$2 ; 8,0 ; 1,8 ; 1,2 ; 0,9 ;$ e $0,9 \%$ com o uso do inoculante, enquanto os teores de FDN, FDA e LIG reduziram em 1,$1 ; 1,7$ e 2,5\%. A estabilidade aeróbia e a recuperação de MS aumentaram em 6,3 e 6,4\%, respectivamente. $\mathrm{O} \mathrm{pH}$ das silagens foi reduzido em média em $3,8 \%$, assim como a produção de gases, que diminuiu em $71,8 \%$. Apesar das reduções nos teores de FDN, FDA e LIG das silagens inoculadas, não houve efeito sobre a DIVMS média, que reduziu somente $0,2 \%$.

Silagens de capins aditivadas com bactérias heterofermentativas apresentaram em média aumento no teor de PB e MS de 8,8 e 0,6\%, redução na recuperação de MS de 1,0\% e diminuição da produção de efluente em 13,1\% (Figura 20). A menor recuperação de MS é o resultado da menor eficiência das bactérias heterofermentativas em decorrência da priorização da produção de ácido acético, etanol e $\mathrm{CO}_{2}$, o que indiretamente sugere incremento da perda de energia (Pahlow et al., 2003).

Segundo Ribeiro et al. (2005), a combinação de bactérias hetero e homofermentativas favorece a redução dos valores de $\mathrm{pH}$, nitrogênio amoniacal e as perdas fermentativas em silagens tratadas. No entanto, nas silagens de capim avaliadas, os valores médios de $\mathrm{pH}$ se elevaram em 1,7\%, a recuperação de MS foi aumentada em 1,6\% e a produção de efluente foi reduzida em $29,6 \%$. Adicionalmente, o uso da combinação resultou em média no aumento dos teores de 


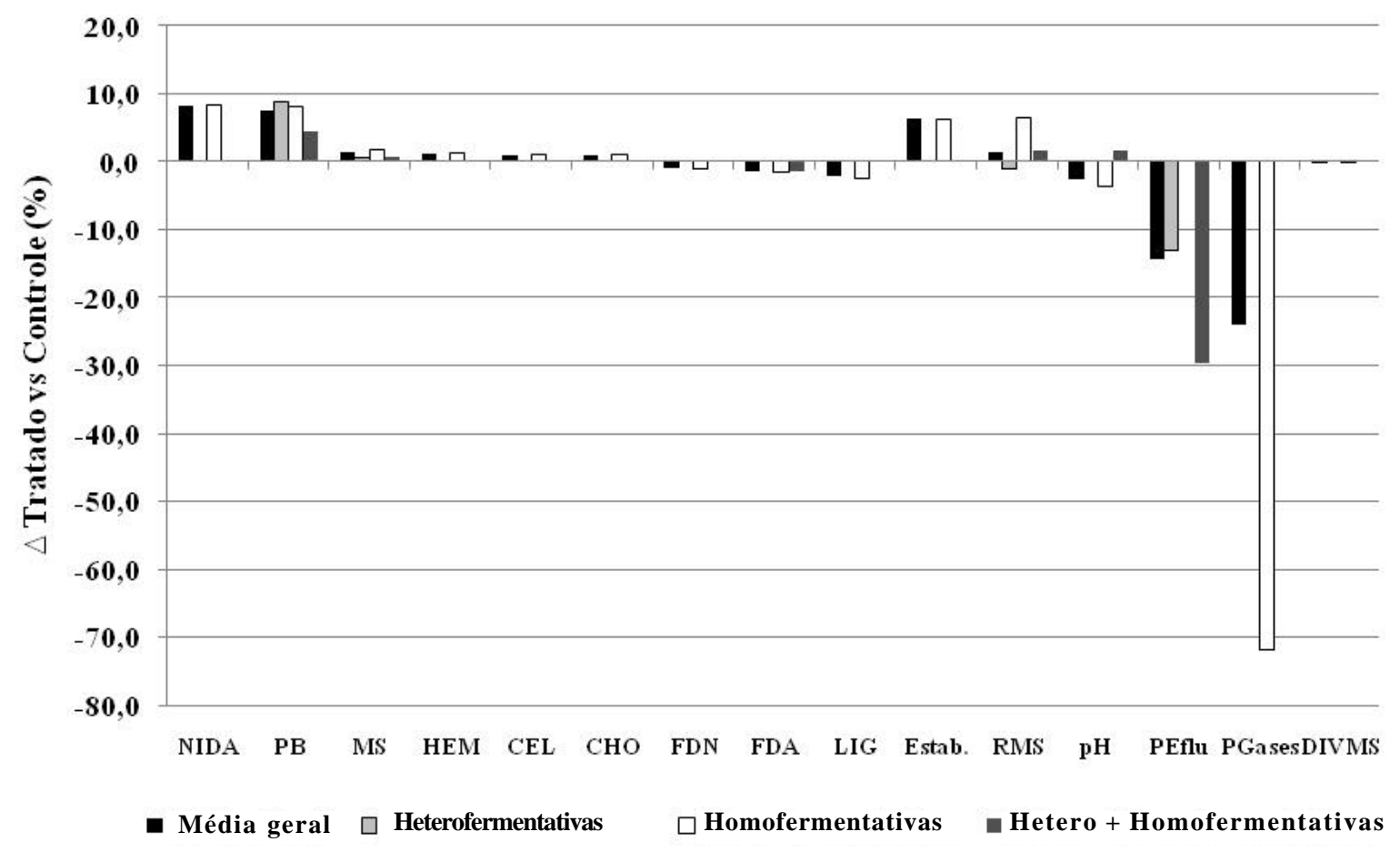

Figura 17 - Média dos diferenciais de resposta entre silagens de capins tratadas com inoculantes e as silagens controle.

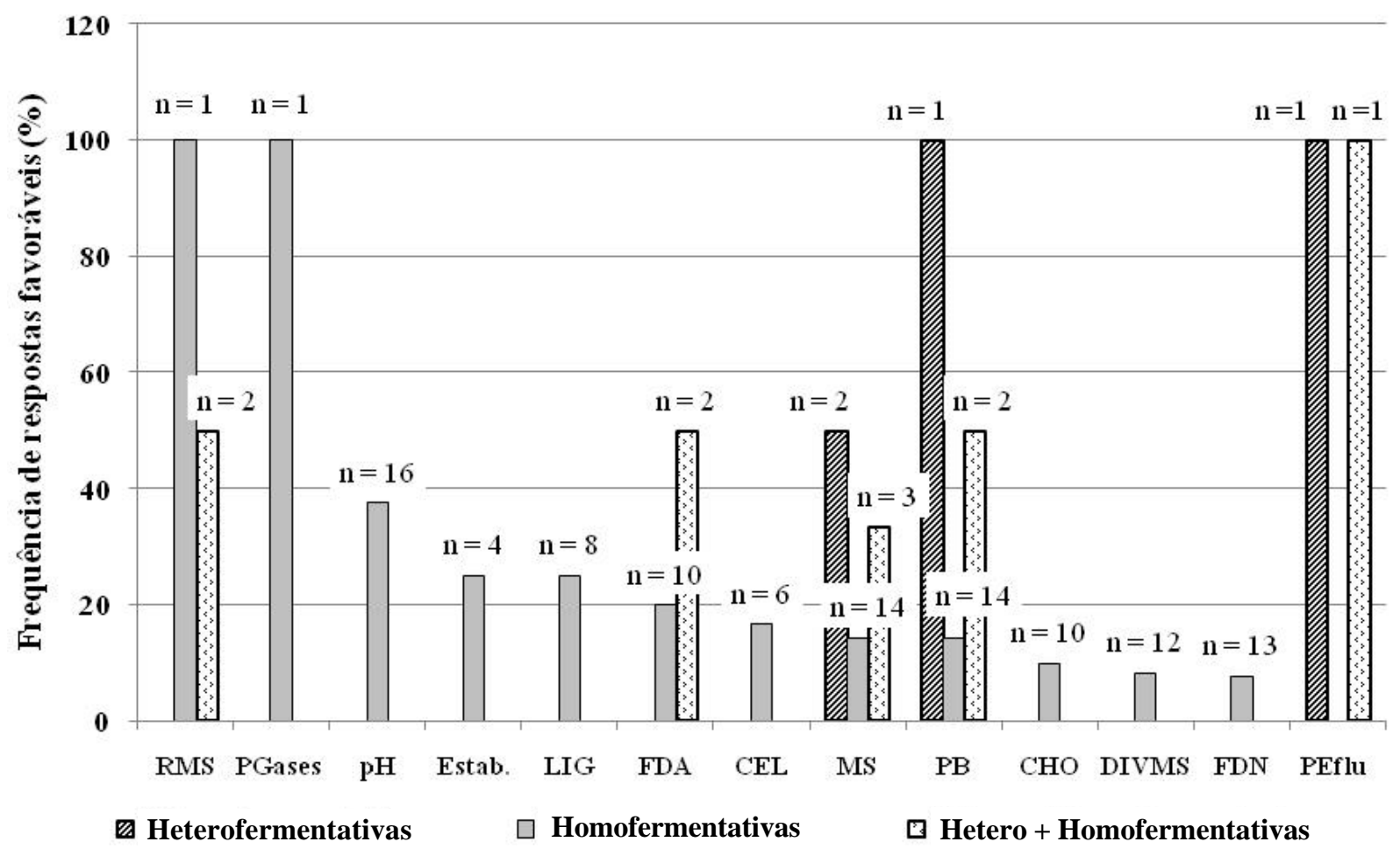

Figura 18 - Frequência de respostas favoráveis em silagens de capins aditivadas com inoculantes microbianos. 


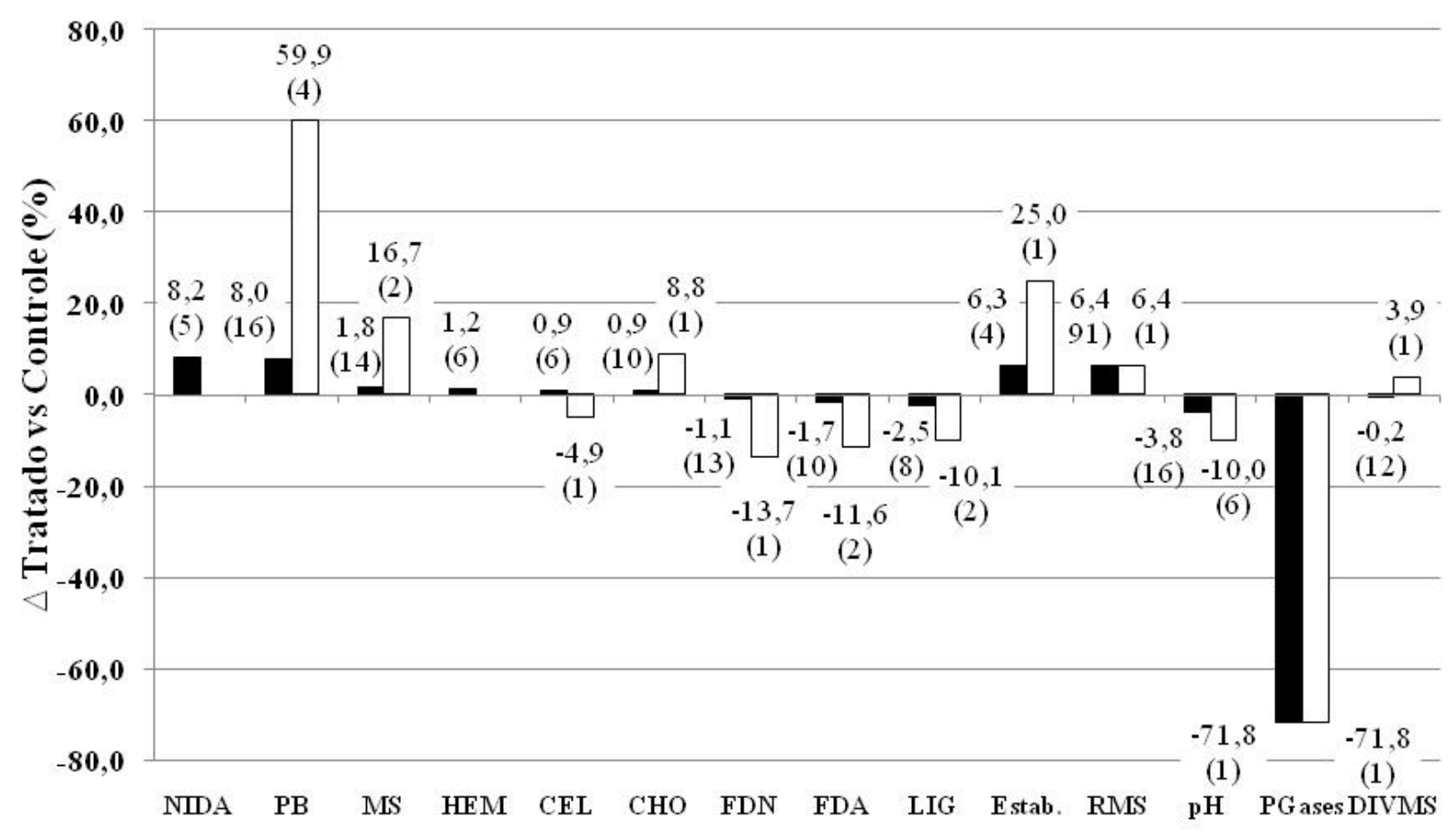

- Média das homofermentativas $\square$ Média das homofermentativas com resultados favoráveis

Figura 19 - Média geral e média dos resultados com respostas favoráveis nos valores do diferencial de resposta entre as silagens de capins aditivadas com bactérias homofermentativas em relação às silagens controle.

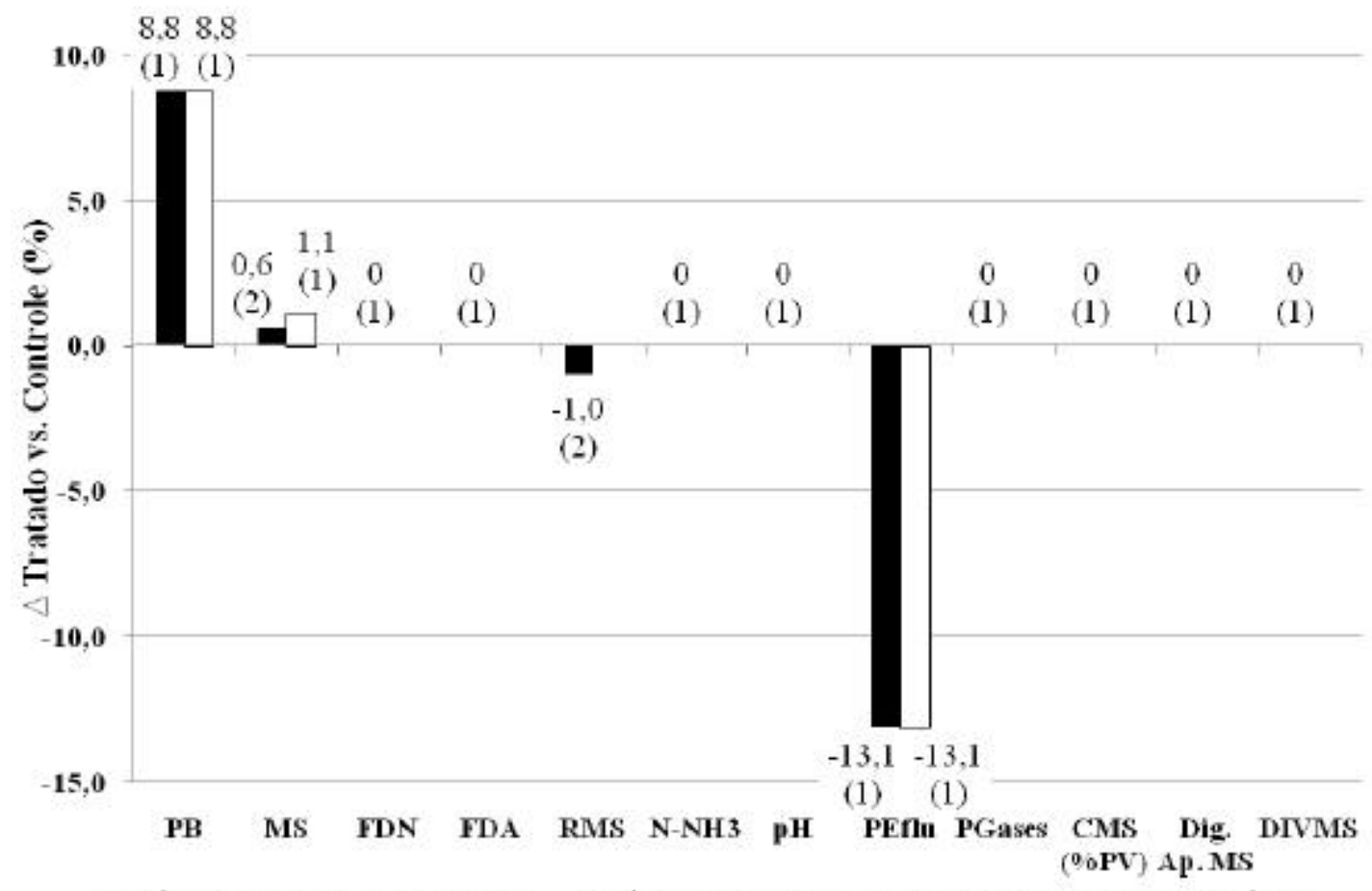

- Média dasheterof ementativas $\quad$ Média das heterofermentativas com respostas favoráveis

Figura 20 - Média geral e média dos resultados com respostas favoráveis nos valores do diferencial de resposta entre as silagens de capins aditivadas com bactérias heterofermentativas em relação às silagens controle. 


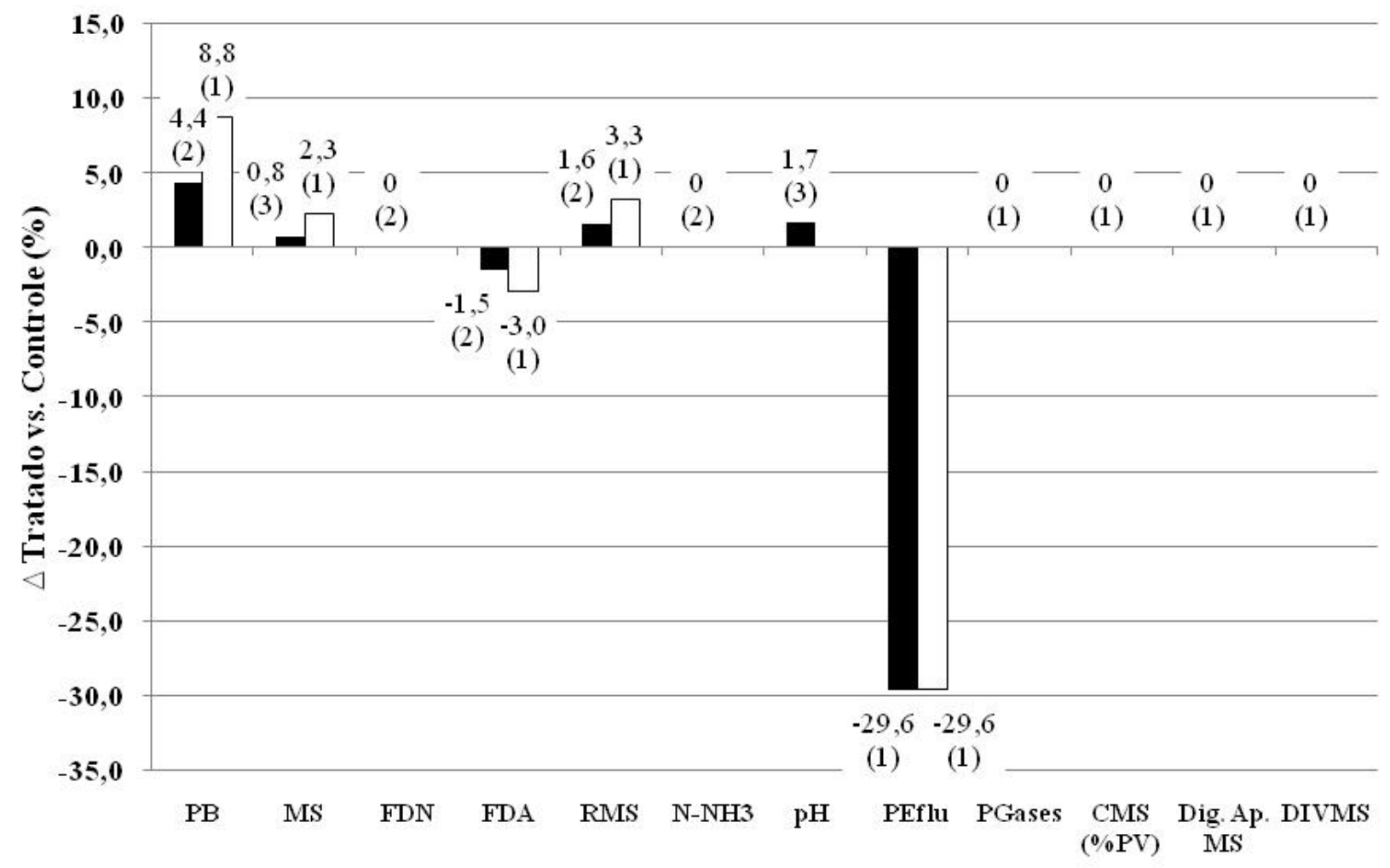

- Média das Hetero+Hom of ermentativas $\square$ Média das Hetero+Hom of ermentativas com resp ostas positivas

Figura 21 - Média geral e média dos resultados com respostas favoráveis nos valores do diferencial de respostas entre as silagens de capins aditivadas com a associação de bactérias hetero e homofermentativas em relação às silagens controle.

PB $(4,4 \%)$ e MS $(0,8 \%)$, e redução nos teores de FDA em $1,5 \%$ (Figura 21).

Os resultados encontrados corroboram com Sollenberger et al. (2003), que reportaram que a principal limitação de se conservar gramíneas tropicais é decorrente dos baixos teores de carboidratos solúveis, que nos trabalhos avaliados foi em média de 1,6\% (Tabela 2), os quais poderiam limitar a ação de bactérias, independentemente da população epifítica da forragem.

O conjunto das respostas em silagens de capins tropicais sugere que a tendência de aumento no teor de proteína nas silagens tratadas se deve mais provavelmente ao efeito de concentração decorrente do desaparecimento parcial nas frações de carboidratos solúveis e de compostos fibrosos, que da redução de proteólise conforme sugerido tradicionalmente na literatura. Isso se deve ao fato de que tanto para bactérias homo, como hetero e a associação de ambas, as relações de $\mathrm{N}$-amoniacal em relação ao $\mathrm{N}$ total mantiveram-se inalteradas, sugerindo ausência de efeito dos inoculantes microbianos sobre a fração $\mathrm{N}$ nessas silagens.

\section{Considerações Finais}

O levantamento dos trabalhos de pesquisa com inoculantes microbianos em silagens no Brasil, na última década, revelou que a comunidade científica tem explorado o assunto com interesse e utilizado de recursos metodológicos com sofisticação progressiva, inclusive em áreas básicas e inovadoras, entretanto, o número de trabalhos que permite comparações devidas para a exploração adequada dos efeitos de aditivos microbianos, ainda pode ser considerado modesto, e os resultados são, em geral, insuficientes, para o estabelecimento de posições conclusivas sobre o assunto.

Revisões de literatura similares apresentadas em outros países, revelam-se mais consistentes quanto as respostas, sobretudo, pelo elevado número de observações disponíveis resultantes dos programas de pesquisa nessa área. Esse fato indica que a comunidade científica brasileira poderia incentivar estudos básicos e, principalmente aplicados, para fortalecer as tendências observadas em resultados preliminares. De forma geral, no conjunto de dados 
analisados notou-se que as respostas favoráveis de maior magnitude foram decorrentes de comparações com menor número de observações. Insistir em comparações previamente exploradas, com o intuito de realizar observações diferenciadas e avaliar variáveis inexploradas poderia indicar o sentido dos investimentos de pesquisa nessa área, sem necessariamente incidir em redundância e pouca originalidade. É fundamental aumentar o número de observações passíveis de comparação para obter conclusões consistentes na utilização dos aditivos microbianos.

Com vistas ao estabelecimento de equações de regressão múltiplas envolvendo respostas de desempenho animal, aos inoculantes microbianos utilizados em silagens, o levantamento de dados revelou a escassez de informações, em especial, no caso do gado leiteiro, e a mínima frequência de exploração dessa linha de pesquisa pela comunidade científica. Cabe ressaltar, que a pesquisa internacional considera os trabalhos aplicados com respostas de desempenho de animais, mandatórios, para a recomendação definitiva de estratégias de utilização desses aditivos.

De forma geral, a frequência de respostas favoráveis em valor nutritivo e padrão de fermentação resultantes de observações mais consolidadas encontradas nesse trabalho, variou entre média e baixa. Essa tendência, embora contraria à alguns resultados mais otimistas, concorda plenamente com a literatura internacional (Muck \& Kung Jr., 1997) e, sugere que a utilização desses aditivos deva gerar expectativa conservadora quanto à magnitude das respostas. Também concordando com os relatos de Kung Jr. \& Muck (1997), as respostas de desempenho animal avaliadas no presente trabalho, quando favoráveis, ocorreram em menor magnitude, sugerindo que na maior parte das vezes os eventuais benefícios da recomendação desses aditivos deva ser justificado por ganhos na preservação de valor nutritivo e contenção de perdas na conservação.

Além disso, o sentido e a intensidade das respostas favoráveis mostraram-se muito dependentes dos grupos de forragens e dos microrganismos estudados, sugerindo a busca por especificidade dessa combinação, e exploração do binômio (forragem vs microrganismo) como linha de pesquisa futura.

\section{Literatura Citada}

ADESOGAN, A.T. Improving forage quality and animal performance with fibrolytic enzymes. In: FLORIDA RUMINANT NUTRITION SYMPOSIUM, 2005. Proceedings... S.L.: 2005. p.91-109.

ANDRADE, J.B.; FERRARI JR., E.; POSSENTI, R.A. et al. Aditivo biológico na ensilagem de cana-de-açúcar tratada com uréia. Boletim da Indústria Animal, v.57, n.2, p.139-149, 2000. ANDRADE, S.J.T.; MELOTTI, L. Efeito de alguns tratamentos sobre a qualidade da silagem de capim-elefante cultivar Napier (Pennisetum purpureum, Schum). Brazilian Journal of Veterinary Research and Animal Science, v.41, p.409$415,2004$.

ANDRADE, S.J.T.; MELOTTI, L. Inoculantes bacterianos na ensilagem do capim-elefante (Pennisetum purpureum, Schum). Brazilian Journal of Veterinary Research and Animal Science, v.40 (supl), p.219-223, 2003.

ÁVILA, C.L.S.; PINTO, J.C.; SUGAWARA, M.S. et al. Qualidade da silagem de cana-de-açúcar inoculada com uma cepa de Lactobacillus buchneri. Acta Scientiarum Animal Science, v.30, n.3, p.255-261, 2008

BACKES, A.A.; SANCHEZ, L.M.B.; GONÇALVES, M.B.F. Desempenho de novilhos Santa Gertrudis confinados submetidos a dietas com diferentes fontes protéicas e silagem de milho, com ou sem inoculante. Revista Brasileira de Zootecnia, v. 30, n.6, p.2121-2125, 2001 (supl.).

BERGAMASCHINE, A.F.; PASSIPIÉRI, M.; VERIANO FILHO, W.V. et al. Qualidade e valor nutritivo de silagens de capimmarandu (B. brizantha cv.Marandu) produzidas com aditivos ou forragem emurchecida. Revista Brasileira de Zootecnia, v.35, n.4, p.1454-1462, 2006.

BERNARDES, T.F.; REIS, R.A.; AMARAL, R.C. Perfil fermentativo, estabilidade aeróbia e valor nutritivo de silagens de capim-Marandu ensilado com aditivos. Revista Brasileira de Zootecnia, v.37, n.10, p.1728-1736, 2008.

BERNARDES, T.F.; REIS, R.A.; SIQUEIRA, G.R. et al. Estabilidade aeróbia da ração total e de silagens de capim-Marandu tratadas com aditivos químicos e bacterianos. Revista Brasileira de Zootecnia, v.36, n.4, p.754-762, 2007.

CASTRO NETO, A.G.; MOLINA, L.R.; GONÇALVES, L.C. et al. Parâmetros de fermentação de silagens de cana-de-açúcar submetidas a diferentes tratamentos. Arquivos Brasileiros de Medicina Veterinária e Zootecnia, v.60, n.5, p.11501156, 2008.

CASTRO, F.G.F; NUSSIO, L.G.; HADDAD, C.M. et al. Perfil microbiológico, parâmetros físicos e estabilidade aeróbia de silagens de capim-Tifton 85 (Cynodon $\mathrm{sp}$.) confeccionadas com distintas concentrações de matéria seca e aplicação de aditivos. Revista Brasileira de Zootecnia, v.35, n.2, p.358-371, 2006.

CHALUPA, W.; EVANS, J.L.; STILLIONS, M.C. Influence of ethanol on rumen fermentation and nitrogen metabolism. Journal of Animal Science, v.23, p.802-807, 1964.

COAN, R.M.; VIEIRA, P.F.; SILVEIRA, R.N. et al. Inoculante Enzimático-bacteriano, composição química e parâmetros fermentativos das silagens dos capins tanzânia e mombaça. Revista Brasileira de Zootecnia, v.34, n.2, p.416-424, 2005.

DRIEHUIS, F.; OUDE ELFERINK, S.J.W.H.; SPOELSTRA, S.F. Anaerobic lactic acid degradation during ensilage of whole crop maize inoculated with Lactobacillus buchneri inhibits yeast growth and improves aerobic stability. Journal of Applied Microbiology, v.87, p.583-594, 1999.

DRIEHUIS, F.; OUDE ELFERINK, S.J.W.H.; Van WIKSELAAR, P.G. Fermentation characteristics and aerobic stability of grass silage inoculated with Lactobacillus buchneri, with or without homofermentative lactic acid bacteria. Grass and Forage Science, v.56, p.330-343, 2001.

FERREIRA, D.A.; GONÇALVES, L.C.; MOLINA, L.R. et al. Características de fermentação da silagem de cana-de-açúcar tratada com uréia, zeólita, inoculante bacteriano e inoculante bacteriano/enzimático. Arquivos Brasileiros de Medicina Veterinária e Zootecnia, v.59, n.2, p.423-433, 2007.

FREITAS, A.W.P.; PEREIRA, J.C.; ROCHA, F.C. et al. Avaliação da qualidade nutricional da silagem de cana-de-açúcar com aditivos microbianos e enriquecida com resíduo da colheita de soja. Revista Brasileira de Zootecnia, v.35, n.1, p.38-47, 2006a. 
FREITAS, A.W.P.; PEREIRA, J.C.; ROCHA, F.C. et al. Características da silagem de cana-de-açúcar tratada com inoculante bacteriano e hidróxido de sódio e acrescida de resíduo da colheita de soja. Revista Brasileira de Zootecnia, v.35, n.1, p.48-59, 2006b.

GENTIL, R.S.; PIRES, A.V.; SUSIN, I. et al. Digestibilidade aparente de dietas contendo silagem de cana-de-açúcar tratada com aditivo químico ou microbiano para cordeiros. Acta Scientiarum Animal Science, v.29, n.1, p.63-69, 2007.

GIMENES, A.L.G.; MIZUBUTI, I.Y.; MOREIRA, F.B. et al. Composição química e estabilidade aeróbia em silagens de milho preparadas com inoculantes bacteriano e/ou enzimático. Acta Scientiarum Animal Science, v.28, n.2, p.153-158, 2006b.

GIMENES, A.L.G.; MIZUBUTI, I.Y.; MOREIRA, F.B. et al. Degradabilidade in situ de silagens de milho confeccionadas com inoculantes bacteriano e/ou enzimático. Acta Scientiarum Animal Science, v.28, n.1, p.11-16, 2006a.

GUIM, A.; ANDRADE, P.; ITURRINO-SCHOCKEN, R.P. et al Estabilidade aeróbica de silagens de capim-elefante (Pennisetum purpureum, Schum) emurchecido e tratado com inoculante microbiano. Revista Brasileira de Zootecnia, v.31, n.6, p.2176-2185, 2002.

JOBIM, C.C.; NUSSIO, L.G.; REIS, R.A. et al. Avanços metodológicos na avaliação da qualidade da forragem conservada. Revista Brasileira de Zootecnia, v.36, suplemento especial, p.101119,2007

JOBIM, C.C.; SARTI, L.L.; SANTOS, G.T. et al. Desempenho animal e viabilidade econômica do uso da silagem de capim-elefante em substituição a silagem de milho para vacas em lactação. Acta Scientiarum Animal Science, v.28, n.2, p.137-144, 2006.

KLEINSCHMIT, D.H.; KUNG JR., L. A meta-analysis of the effects of Lactobacillus buchneri on the fermentation and aerobic stability of corn and grass and small-grain silages. Journal of dairy Science, v.89, p.4005-4013, 2006.

KUNG JR., L.; MUCK, R.E. Animal response to silage additives. In: Silage : field to feedbunk. NRAES-99. Hershey: North America Conference, Ithaca: Northeast Reg. Agric. Eng. Serv., Coop. Ext., 1997. p.200-210

KUNG JR., L.; STOKES, M.R.; LIN, C.J. Silage additives. In: BUXTON, D.R.; MUCK, R.E.; HARRISON, J.H. (Eds.) Silage science and technology. Wisconsin: ASA; CSSA; SSSA, 2003. p.305-360.

LOURES, D.R.S.; NUSSIO, L.G.; PAZIANI, S.F. et al. Composição bromatológica e produção de efluente de silagens de capimtanzânia sob efeitos do emurchecimento, do tamanho de partícula e do uso de aditivos biológicos. Revista Brasileira de Zootecnia, v.34, n.3, p.726-735, 2005.

MENDES, C.Q.; SUSIN, I.; NUSSIO, L.G. et al. Efeito do Lactobacillus buchneri na fermentação, estabilidade aeróbia e no valor nutritivo de silagem de cana-de-açúcar. Revista Brasileira de Zootecnia, v.37, n.12, p.2191-2198, 2008a.

MENDES, C.Q.; SUSIN, I.; PIRES, A.V. et al. Desempenho, parâmetros da carcaça e comportamento ingestivo de cordeiros alimentados com cana-de-açúcar ensilada ou in natura. Arquivos Brasileiros de Medicina Veterinária e Zootecnia, v.60, n.3, p.733-740, 2008b.

MUCK, R.E. Factors influencing silage quality and their implications for management. Journal of Dairy Science, v.71, p.29923002,1988

MUCK, R.E.; KUNG Jr., L. Effects of silage additives on ensiling. Silage: field to feedbunk. NRAES-99. Hershey: North America Conference, Ithaca: Northeast Reg. Agric. Eng. Serv., Coop. Ext., 1997. p.187-199

NSEREKO, V.L.; SMILEY, B.K.; RUTHERFORD, W.M. et al Influence of inoculating forage with lactic acid bacterial strains that produce ferulate esterase on ensilage and ruminal degradation of fiber. Animal Feed Science and Technology, v.145, p.122$135,2008$.
OUDE ELFERINK, S.J.W.H.; KROONEMAN, J.; GOTTSCHAL, J.C. et al. Anaerobic conversion of lactic acid to acetic acid and 1,2 propanediol by Lactobacillus buchneri. Applied Environmental Microbiology, v. 67, p.125-132, 2001.

PAHLOW, G.; MUCK, R.E.; DRIEHUIS, F. et al. Microbiology of ensiling. In: BUXTON, D.R.; MUCK, R.E.; HARRISON, J.H. (Eds.) Silage science and technology. Wisconsin: ASA; CSSA; SSSA, 2003. p.31-93.

PATRIZI, W.L.; MADRUGA JR., C.R.F.; MINETTO, T.P. et al. Efeito de aditivos biológicos comerciais na silagem de capimelefante (Pennisetum purpureum Schum). Arquivos Brasileiros de Medicina Veterinária e Zootecnia, v.56, n.3, p.392397, 2004

PAZIANI, S.F.; NUSSIO, L.G.; LOURES, D.R.S. Influência do teor de matéria seca e do inoculante bacteriano nas características físicas e químicas da silagem de capim Tanzânia. Acta Scientiarum Animal Science, v.28, n.3, p.265-271, 2006a.

PAZIANI, S.F.; NUSSIO, L.G.; PIRES, A.V. efeito do emurchecimento e do inoculante bacteriano sobre a qualidade da silagem de capim Tanzânia e o desempenho de novilhas. Acta Scientiarum Animal Science, v.28, n.4, p.393-400, 2006b.

PEDROSO, A.F.; FREITAS, A.R.; SOUZA, G.B. Efeito de inoculante bacteriano sobre a qualidade da silagem e perda de matéria seca durante a ensilagem de sorgo. Revista Brasileira de Zootecnia, v.29, n.1, p.48-52, 2000.

PEDROSO, A.F.; NUSSIO, L.G.; BARIONI JR., W. et al. Performance of Holstein heifers fed sugarcane silages treated with urea, sodium benzoate or Lactobacillus buchneri. Pesquisa Agropecuária Brasileira, v.41, n.4, p.649-654, 2006.

PEDROSO, A.F.; NUSSIO, L.G.; LOURES, D.R.S. et al. Efeito do tratamento com aditivos químicos e inoculantes bacterianos nas perdas e na qualidade de silagens de cana-de-açúcar.Revista Brasileira de Zootecnia, v.36, n.3, p.558-564, 2007

PEREIRA, O.G.; ROCHA, K.D.; FERREIRA, C.L.L.F. Composição química, caracterização e quantificação da população de microrganismos em capim-elefante cv. Cameroon (Pennisetum purpureum, Schum.) e suas silagens. Revista Brasileira de Zootecnia, v.36, n.6, p.1742-1750, 2007.

RIBEIRO, J.L.; QUEIROZ, O.C.M.; NUSSIO, L.G. Desenvolvimento de aditivos microbianos para ensilagem: realidade e perspectivas. In: REIS, R.A; SIQUEIRA, G.R.; BERTIPAGLIA, L.M.A. et al. (Eds.) Volumosos na produção de ruminantes. Jaboticabal: Funep, 2005. p.1-23.

RIBEIRO, J.L.; NUSSIO, L.G.; MOURÃO, G.B. et al. Efeitos de absorventes de umidade e de aditivos químicos e microbianos sobre o valor nutritivo, o perfil fermentativo e as perdas em silagens de capim-marandu. Revista Brasileira de Zootecnia, v.38, n.2, p.230-239, 2009.

ROCHA, K.D.; PEREIRA, O.G.; VALADARES FILHO, S.C. et al. Valor nutritivo de silagens de milho (Zea mays L.) produzidas com inoculantes enzimo-bacterianos. Revista Brasileira de Zootecnia, v.35, n.2, p.389-395, 2006.

RODRIGUES, P.H.M.; ANDRADE, S.J.T.; FERNANDES, T. et al. Valor nutritivo da silagem de capim-elefante cultivar Napier (Pennisetum purpureum, Schum) inoculada com bactérias ácidoláticas. Acta Scientiarum, v.23, n.4, p.809-813, 2001.

RODRIGUES, P.H.M.; ANDRADE, S.J.T.; RUZANTE, J.M. et al. Valor nutritivo da silagem de milho sob o efeito da inoculação de bactérias ácido-láticas. Revista Brasileira de Zootecnia, v.31, n.6, p.2380-2385, 2002.

RODRIGUES, P.H.M.; LOPES, T.F.T.; ANDRADE, S.J.T. et al. Adição de inoculantes microbianos sobre a composição química e perfil fermentativo da silagem de capim-elefante (Pennisetum purpureum, Schum). Acta Scientiarum Animal Science, v.25, n.2, p.397-402, 2003

RODRIGUES, P.H.M.; RUZANTE, J.M.; SENATORE, A.L. et al. Avaliação do uso de inoculantes microbianos sobre a qualidade 
fermentativa e nutricional da silagem de milho. Revista Brasileira de Zootecnia, v.33, n.3, p.538-545, 2004.

RODRIGUES, P.H.M.; SENATORE, A.L.; ANDRADE, S.J.T. et al. Efeitos da adição de inoculantes microbianos sobre a composição bromatológica e perfil fermentativo da silagem de sorgo produzida em silos experimentais. Revista Brasileira de Zootecnia, v.31, n.6, p.2373-2379, 2002a.

RODRIGUES, P.H.M.; SENATORE, A.L.; LUCCI, C.S. et al. Valor nutritivo da silagem de sorgo tratada com inoculantes enzimomicrobianos. Acta Scientiarum, v.24, n.4, p.1141-1145, 2002b.

ROTH, G.; UNDERSANDER, D. Silage additives. In: Corn silage production management and feeding. Madison: Madison American Society of Agronomy, 1995. p.27-29.

SANTOS, M.C.; NUSSIO, L.G.; MOURÃO, G.B. et al. Nutritive value of sugarcane silage treated with chemical additives. Scientia Agricola, v.66, n.2, p.159-163, 2009.

SCHMIDT, P.; MARI, L.J.; NUSSIO, L.G. et al. Aditivos químicos e biológicos na ensilagem de cana-de-açúcar. 1. Composição química das silagens, ingestão, digestibilidade e comportamento ingestivo. Revista Brasileira de Zootecnia, v.36 (supl.), n.5, p.1666-1675, 2007a.

SCHMIDT, P.; NUSSIO, L. G.; ZOPOLLATTO, M. et al. Aditivos químicos ou biológicos na ensilagem de cana-de-açúcar. 2 . Parâmetros ruminais e degradabilidade da matéria seca e das frações fibrosas. Revista Brasileira de Zootecnia, v.36 (supl.), n.5, p.1676-1684, 2007b.

SILVA, A.V.; PEREIRA, O.G.; GARCIA, R. et al. Composição bromatológica e digestibilidade in vitro da matéria seca de silagens de milho e sorgo tratadas com inoculantes microbianos. Revista Brasileira de Zootecnia, v.34, n.6, p.1881-1890, 2005 .
SILVA, A.V.; PEREIRA, O.G.; VALADARES FILHO, S.C. et al. Consumo e digestibilidades dos nutrientes em bovinos recebendo dietas contendo silagens de milho e sorgo, com e sem inoculante microbiano. Revista Brasileira de Zootecnia, v. 35, n.6, p.2469-2478, 2006.

SIQUEIRA, G.R.; REIS, R.A.; SCHOCKEN-ITURRINO, R.P. et al. Associação entre aditivos químicos e bacterianos na ensilagem de cana-de-açúcar. Revista Brasileira de Zootecnia, v.36, n.4, p.789-798, 2007a.

SIQUEIRA, G.R.; REIS, R.A.; SCHOCKEN-ITURRINO, R.P. et al. Perdas de silagens de cana-de-açúcar tratadas com aditivos químicos e Bacterianos. Revista Brasileira de Zootecnia, v.36 (supl.), n.6, p.2000-2009, 2007b.

SOLLENBERGER, L.E.; REIS, R.A.; NUSSIO, L.G. Conserved forage. In: Warm season grasses. Madison: ASA, CSSA, SSSA, 2004. p.355-387.

SOUSA, D.P.; MATTOS, W.R.S.; NUSSIO, L.G. et al. Efeito de aditivo químico e inoculantes microbianos na fermentação e no controle da produção de álcool em silagens de cana-de-açúcar. Revista Brasileira de Zootecnia, v.37, n.9, p.1564-1572, 2008.

VIEIRA, F.A.P.; BORGES, I.; STEHLING, C.A.V. et al. Qualidade de silagens de sorgo com aditivos Arquivos Brasileiros de Medicina Veterinária e Zootecnia, v.56, n.6, p.764-772, 2004.

VILELA, D. Aditivos para silagens de plantas de clima tropical. In: REUNIÃO ANUAL DA SOCIEDADE BRASILEIRA DE ZOOTECNIA, 35., 1998, Botucatu. Anais... Botucatu: Sociedade Brasileira de Zootecnia, 1998.

YILDIRIM, M. Purification of buchnericin LB produced by Lactobacillus buchneri LB. Journal of Biology, v.25, p.5965, 2001. 